УДК 576.895.1(285:571)

Светлой памяти нашего друга АНДРЕЕВА Александра Владимировича выдающегося орнитолога, неутомимого исследователя природы СевероВостока России, внесшего неоценимый личный вклад в успех экспедиции 2018 г. на озера Дарпирской впадины в отрогах хребта Черского.

\title{
ПАРАЗИТЫ РЫБ ГОРНЫХ ОЗЕР БАССЕЙНА ВЕРХНЕЙ КОЛЫМЫ. 1. Озера Большой и Малый Дарпир
}

\author{
Поспехов В. В., Атрашкевич Г. И., Орловская О. М., Михайлова Е. И. \\ ФГБУН Институт биологических проблем Севера ДВО РАН, г. Магадан \\ E-mail: vitalijpospehov@gmail.com
}

\begin{abstract}
Приведены первые сведения о паразитофауне рыб горных озер Большой и Малый Дарпир южных отрогов хребта Черского (Момский район Республики Саха (Якутия)). Исследовано 7 видов рыб, у которых обнаружены 34 вида паразитов - 33 вида гельминтов и 1 вид паразитических копепод, относящихся к 22 родам, 16 семействам, 12 отрядам, 7 классам 4 типов животного царства. По числу видов среди гельминтов полностью доминируют трематоды 16; вдвое меньше цестод -8 видов и далее следуют нематоды и скребни -5 и 4 вида соответственно. Наибольшим разнообразием паразитов выделяются восточносибирский хариус (22 вида) и арктический голец (19 видов). Далее по числу видов паразитов следуют колымский подкаменщик (13 видов), обыкновенный валек (10 видов), сибирский чукучан (9 видов), тонкохвостый налим и обыкновенный гольян (по 7 видов). Лишь один вид паразитов - скребень Neoechinorhynchus salmonis Ching, 1984 - является общим для всех исследованных рыб. Второй вид скребней - Pseudoechinorhynchus borealis (Linstow, 1901), не обнаруженный только у обыкновенного валька, впервые отмечен у рыб Охотско-Колымского края и у сибирского чукучана как нового дефинитивного хозяина.
\end{abstract}

Ключевые слова: ихтиопаразитофауна, цестоды, трематоды, нематоды, скребни, горные озера, бассейн Верхней Колымы.

DOI: 10.34078/1814-0998-2021-4-89-108

\section{ВВЕДЕНИЕ}

Обширные горные районы Охотско-Колымского края, в административных границах составляющего территорию современной Магаданской области с сопредельными районами Саха (Якутии), Чукотского автономного округа и Камчатского края, в паразитологическом отношении являются одними из наименее изученных на Северо-Востоке России. До недавнего времени основное внимание в эколого-фаунистическом изучении паразитов рыб этой территории было сосредоточено, главным образом, на крупнейших охотоморских лососевых реках и лишь отчасти - на отдельных озерах в поймах этих рек и на приморских равнинах (Волобуев и др., 2001; Михайлова и др., 2004; Атрашкевич и др., 2005; Поспехов и др., 2010, 2014, 2020; Поспе-

(C) Поспехов В. В., Атрашкевич Г. И., Орловская О. М., Михайлова Е. И., 2021 хов, 2013; и др.). По Республике Саха (Якутия) имеется современная сводка В. А. Однокурцева (2015) о паразитах позвоночных животных, включая рыб, свидетельствующая о полном отсутствии ихтиопаразитологических сведений из районов Верхней Колымы на якутской территории. Заметим, что публикации по паразитофауне рыб Верхнеколымского бассейна и в пределах Магаданской области крайне малочисленны (Пугачев, 1984; Леонов, Обушенков, 1985; Никишин, Леонов, 2000). Остаются не изученными многочисленные горные озера в бассейнах рек, образующих Колыму. В этом отношении до последнего времени приходилось ориентироваться лишь на единственную краткую работу по гельминтам четырех видов рыб широко известного оз. Джека Лондона (юго-восточная оконечность горных цепей Черского) - восточносибирского хариуса, сибирского усатого гольца, обыкновенного гольяна и колымского подкаменщика (Леонов, 1986). 
Природа басс. Верхней Колымы многие десятилетия подвергается интенсивному разрушительному воздействию горнорудной промышленности, осуществляющей добычу золота, серебра, других ценных металлов и полезных ископаемых. При этом в некоторых горных областях Верхнеколымского бассейна еще сохранились отдельные, труднодоступные и малоизмененные антропогенной деятельностью районы, привлекающие своей первозданной природной красотой и изобилующие уникальными озерноречными системами и «гольцово-хариусовыми» озерами различной величины и генезиса. В связи с этим крайне востребованным оказался природоохранный проект ученых Института биологических проблем Севера ДВО РАН о создании в Верхнеколымском нагорье и отрогах хр. Черского Национального природного парка «Черский», предусматривающий необходимость проведения на этой территории широкого спектра научных исследований, в первую очередь биологических, включая и паразитологическое направление (Андреев и др., 2020).

Представленная работа открывает цикл публикаций о паразитах озерных рыб ОхотскоКолымского края, по которым в лаборатории экологии гельминтов ИБПС ДВО РАН накопился большой фактический материал, включая сборы последнего десятилетия (2012-2021 гг.). В настоящем исследовании приводятся первые сведения о паразитофауне рыб наиболее труднодоступных ледниково-тектонических оз. Большой и Малый Дарпир (Б. Дарпир и М. Дарпир). При этом заметим, что часть гельминтологического материала из оз. Б. Дарпир уже использована одним из авторов для анализа распространения скребня Neoechinorhynchus tumidus Van Cleave et Bangham, 1949 в Северной Азии (Михайлова, 2020).

\section{МАТЕРИАЛ И МЕТОДЫ}

Дарпирская впадина в отрогах хр. Черского, находящаяся в административных границах северо-восточной части Сусуманского района Магаданской области и юго-восточной части Момского района Саха (Якутии), расположена в окружении горных массивов на высотах 800-1100 м н. у. м. Север Дарпирской впадины ограничен восточными склонами хр. УлаханЧистай и западными предгорьями гряды Омулевских гор. Здесь и расположены крупные олиготрофные озера ледникового происхождения, занимающие тектонические провалы - Б. Дарпир $\left(64^{\circ} 08^{\prime} 15^{\prime \prime}\right.$ с. ш., $147^{\circ} 59^{\prime} 30^{\prime \prime}$ в. д.) и М. Дарпир $\left(64^{\circ} 03^{\prime} 23^{\prime \prime}\right.$ с. ш., $148^{\circ} 02^{\prime} 33^{\prime \prime}$ в. д.) (Андреев и др., 2020). Протяженность первого озера около12 км и глубина до 65 м, протяженность второго - около 4 км и глубина до 30 м. Когда-то в прошлом эти озера были единым водоемом, а в настоящее время они соединены широкой извилистой протокой длиной около 4 км. Воды озер Дарпир через р. Дарпир-Сиен последовательно соединяются с рр. Дарпир-Юрях, Рассоха и Ясачная, имея конечную связь с р. Колыма уже в ее среднем течении (рис. 1).

Как известно, эколого-фаунистические сведения о паразитах отражают и вполне конкретные особенности экологии их облигатных хозяев (характер трофических связей, миграций, межвидовых отношений в ихтиоценозах и др.). В конечном итоге эти сведения в совокупности с изучением жизненных циклов паразитов дают возможность составить адекватное представление о популяционной роли тех или иных видов рыб в структурно-функциональной организации паразитарных систем массовых и патогенных видов в конкретных гидроценозах - горных озерноречных системах басс. Верхней Колымы.

В ходе экспедиции на озера Дарпир в июлеавгусте 2018 г. паразитологическому исследованию подвергнуто 188 экз. рыб семи видов: Salvelinus alpinus complex (L., 1758) - арктический голец; Thymallus arcticus pallasi Vallenciennes, 1848 - восточносибирский хариус; Prosopium cylindraceum (Pallas, 1784) - обыкновенный валек; Catostomus catostomus rostratus (Tilesius, 1814) - сибирский чукучан; Lota lota leptura Hubbs et Schuitz, 1941 - тонкохвостый налим; Phoxinus phoxinus (L., 1758) - обыкновенный гольян и Cottus kolymensis Sideleva et Goto, 2012 колымский подкаменщик (табл. 1).

По опросным сведениям, в оз. Б. Дарпир, недалеко от истока р. Дарпир-Сиен, встречается также ленок - Brachymystax lenok (Pallas, 1773), отсутствовавший в наших уловах, которые осуществлялись ставными сетями и удебными орудиями лова. Результаты этих обловов показали, что в оз. Б. Дарпир преобладали арктический голец, обыкновенный валек и реже встречался восточносибирский хариус. Сибирский чукучан и тонкохвостый налим в уловах оз. Б. Дарпир встречались редко, всего отловлено 5 и 8 экз. соответственно. В оз. М. Дарпир основу уловов составляли сибирский чукучан и восточносибирский хариус, реже попадался обыкновенный валек, а арктический голец отловлен в единственном экземпляре. Тонкохвостого налима в этом озере отловить не удалось вовсе.

Определение рыб в полевых условиях и их названия приведены по И. А. Черешневу с соавторами (2001). Значительная часть выловленных рыб каждого вида вскрыта в полевых условиях с соблюдением всех методических приемов для сбора полноценной коллекции паразитов в виде фиксированных образцов для последующего камерального изучения (Быховская-Павловская, 1985). 


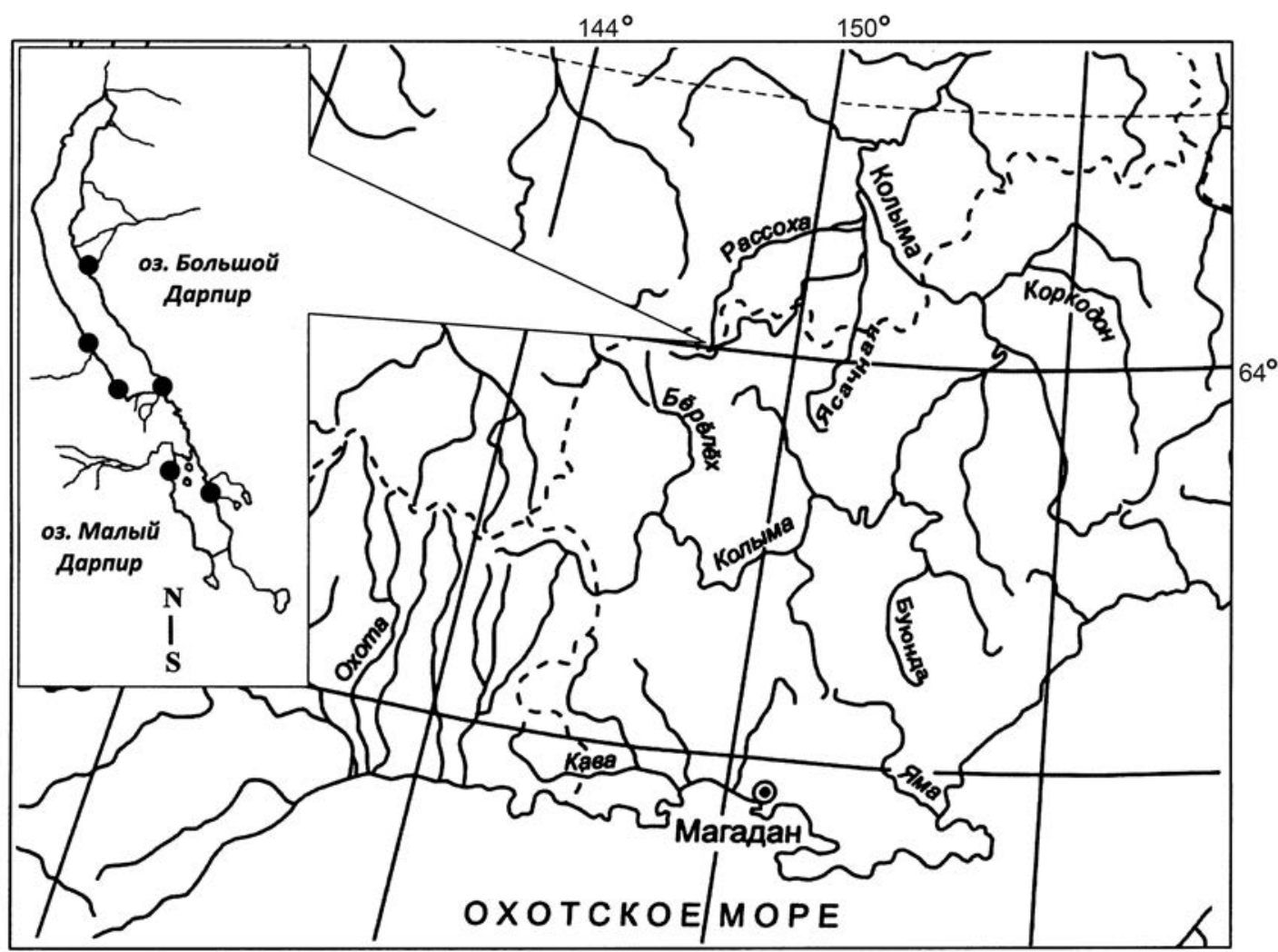

Рис. 1. Район ихтиопаразитологических исследований на озерах Дарпир (точками отмечены места сбора оригинального материала)

Fig. 1. The area of fish parasitology studies at the Darpir lakes (dots mark sites of the original material sampling)

Таблица 1. Размерно-весовые показатели рыб, обследованных в озерах Дарпир

Table 1. Size and weight parameters of fish examined at the Darpir lakes

\begin{tabular}{|l|c|c|c|}
\hline \multicolumn{1}{|c|}{ Виды рыб } & $\begin{array}{c}\text { Обследовано } \\
\text { рыб, экз. }\end{array}$ & $\begin{array}{c}\text { Длина тела } \\
\text { по Смитту, см }\end{array}$ & Масса тела, г \\
\hline Salvelinus alpinus complex & 31 & $\frac{30.0}{24.6-66.7}$ & $\frac{293.8}{130.0-3060.0}$ \\
\hline Thymallus a. pallasi & 46 & $\frac{32.0}{25.0-40.0}$ & $\frac{323.4}{150.0-540.0}$ \\
\hline Prosopium cylindraceum & 23 & $\frac{35.2}{27.5-38.8}$ & $\frac{388}{170.0-520.0}$ \\
\hline Lota l. leptura & 8 & $\frac{54.6}{33.7-69.0}$ & $\frac{781.0}{250.0-1420.0}$ \\
\hline Catostomus c. rostratus & 25 & $\frac{39.0}{28.2-45.8}$ & $\frac{656.4}{320.0-940.0}$ \\
\hline Phoxinus phoxinus & 43 & $\frac{6.0}{4.3-7.3}$ & - \\
\hline Cottus kolymensis & 12 & $\frac{4.5}{2.5-9.5}$ & - \\
\hline
\end{tabular}

Примечание. Над чертой указаны средние значения, под чертой - лимит.

У другой части рыб поштучно отпрепарированы глаза и внутренние органы, зафиксированные в 4 \%-ном формалине (гольяны и подкаменщики фиксировались целиком) для последующей их обработки и изучения выявленных паразитов в лабораторных условиях. Камеральное изучение паразитов проведено по известным, стандартным методикам на временных и постоянных препаратах. В работе использованы микроскопы Amplival (Carl Zeiss Jena) и ZeissAxio Imager D1. 
Оригинальные рисунки выполнены с помощью рисовального аппарата РА-6 с небольшой обработкой изображений в программе Adobe Photoshop.

В аннотированном списке собранной коллекции паразитических червей за основу принят таксономический порядок, предложенный в сводках О. Н. Пугачева (2002, 2003, 2004), с учетом ряда современных данных (Kuchta et al., 2008; Caira et al., 2014; Wayland et al., 2015; Waeschenbach et al., 2017; Reier et al., 2020); при этом виды рыб, являющиеся новыми дефинитивными хозяевами конкретных видов паразитов, отмечены звездочкой.

В эколого-фаунистическом анализе использованы общепринятые показатели зараженности хозяев паразитами: экстенсивность инвазии (ЭИ, \%, экз.); интенсивность инвазии (ИИ, экз.) и индекс обилия (ИО). Использованы известные сокращения для обозначения возрастных и стадийных характеристик паразитов: ad. взрослые особи; juv. - молодые особи; pl. - плероцеркоиды цестод; met. - метацеркарии трематод. Промеры в описаниях трематод даны в микрометрах.

\section{РЕЗУЛЬТАТЫ И ОБСУЖДЕНИЕ}

Аннотированный список паразитов рыб
оз. Большой и Малый Дарпир
Тип РLATHELMINTHES
Класс CESTODA
Отр. Spathebothriidea
Сем. Суathocephalidae
1. Cуathocephalus truncatus (Pallas, 1781)

Хозяева: арктический голец, восточносибирский хариус.

Локализация: пилорические придатки кишечника.

Широко распространенный в водоемах Голарктики вид, ареал которого совпадает с ареалом лососевидных рыб (Определитель..., 1987; Пугачев, 2002; Буторина и др., 2011; Однокурцев, 2015). Жизненный цикл паразита реализуется с участием одного промежуточного хозяина - различных видов пресноводных гаммарид (Протасова, Ройтман, 1995; Пугачев, 2002). В оз. Кроноцкое на Камчатке промежуточным хозяином цестоды является бокоплав Gammarus lacustris G. O. Sars, 1864 (Соколов, Гордеев, 2014). Этот же вид бокоплава обнаружен нами в желудках рыб четырех видов, в т. ч. восточносибирского хариуса, и, очевидно, также служит промежуточным хозяином C. truncatus в озерах Дарпир. В тундровых водоемах Чукотки для C. truncatus отмечено явление прогенеза (Протасова, Ройтман, 1995). Паразит обнаружен у камчатского хариуса в басс. р. Тауй (Поспехов и др., 2020), а также у нейвы (Salvelinus neiva Taranetz, 1933) в оз. Мак-Мак и у мальмы (Salvelinus malma (Wal- baum, 1792)) в оз. Чистое басс. р. Ола Тауйской губы Охотского моря (Атрашкевич и др., 2005).

Отр. Caryophyllidea

Сем. Caryophyllaeidae

2. Glaridacris catostomi Cooper, 1920

Хозяин: сибирский чукучан.

Локализация: кишечник.

Специфичный паразит чукучановых рыб, широко распространенный в Северной Америке. На Северо-Востоке Азии ареал вида ограничен бассейнами рр. Колыма и Индигирка, где обитает сибирский чукучан (Пугачев, 1984; Определитель..., 1987; Однокурцев, 2015). Жизненный цикл цестоды протекает с участием олигохет родов Limnodrilus, Aulodrilus, Peloscolrx, Tubifex, Uncinais, Ilyodrilus как промежуточных хозяев (Пугачев, 2002). G. catostomi отмечен у сибирского чукучана в русловых участках рек басс. Верхней Колымы (Пугачев, 1984; Леонов, Обушенков, 1985; Никишин, Леонов, 2000).

\section{Отр. Bothriocephalidea}

\section{Сем. Triaenophoridae}

3. Eubothrium salvelini Schrank, 1790

Хозяева: арктический голец, восточносибирский хариус.

Локализация: пилорические придатки, кишечник.

Широко распространенный в водоемах Голарктики вид, ареал которого совпадает с ареалом лососевидных рыб, а жизненный цикл реализуется с участием различных видов пресноводных копепод в качестве первых промежуточных хозяев (Пугачев, 1984, 2002; Определитель..., 1987; Буторина и др., 2011). Обычный паразит проходных лососевых рыб и хариусов Северного Охотоморья (Поспехов и др., 2014, 2020), отмеченный также у нейвы в оз. Мак-Мак, у мальмы и кунджи (Salvelinus leucomaenis (Pallas, [1814])) в оз. Чистое басс. р. Ола Тауйской губы Охотского моря (Атрашкевич и др., 2005).

\section{Отр. Diphyllobothriidea}

\section{Сем. Diphyllobothriidae}

4. Dibothriocephalus dendriticus (Nitzsch, 1824), pl. 1824).

(Syn. Diphyllobothrium dendriticum Nitzsch,

Синонимия по: Waeschenbach et al., 2017.

Хозяева: арктический голец, восточносибирский хариус.

Локализация: поверхность желудка и кишечника.

На стадии плероцеркоида (как правило, в относительно крупных, округлых капсулах) - широко распространенный полостной и органный паразит различных пресноводных рыб Голарктики (Определитель..., 1987; Пугачев, 2002; Буторина и др., 2011; Однокурцев, 2015). Личиночное развитие лентеца поочередно осуществляется в 
планктонных ракообразных (первые промежуточные хозяева) и в пресноводных рыбах (вторые, дополнительные промежуточные хозяева). Рыбы, в первую очередь хищные, одновременно могут выполнять и роль паратенических хозяев. Окончательные хозяева $D$. dendriticus различные рыбоядные птицы, главным образом чайковые (Делямуре и др., 1985). Паразит широко распространен у пресноводных рыб ОхотскоКолымского края (Атрашкевич и др., 2005; Поспехов и др., 2014). Имеет признанное медиковетеринарное значение (Делямуре и др., 1985).

5. Dibothriocephalus ditremus (Creplin, 1825), pl.

(Syn. Diphyllobothrium ditremum (Creplin, 1825)).

Синонимия по: Waeschenbach et al., 2017.

Хозяева: арктический голец, восточносибирский хариус, сибирский чукучан*.

Локализация: поверхность желудка и кишечника.

Все вышесказанное о распространении и цикле развития $D$. dendriticus в общем относится и к данному виду. Однако облигатными дефинитивными хозяевами этой цестоды в основном являются гагары и крохали (Делямуре и др., 1985). D. ditremus - обычный паразит многих пресноводных рыб Охотско-Колымского края, в т. ч. в о3. Чукча, Чистое и Глухое басс. рек Тауйской губы Охотского моря (Атрашкевич и др., 2005, 2011; Поспехов и др., 2014). В отличие от первого вида лентецов медико-ветеринарное значение D. ditremus невелико (Делямуре и др., 1985).

6. Ligula intestinalis (L., 1758), pl.

Хозяин: обыкновенный гольян.

Локализация: полость тела.

Широко распространенный в Голарктике паразит пресноводных рыб, преимущественно карповых. Первые промежуточные хозяева - планктонные ракообразные Calanoida и Cyclopoida. Взрослые цестоды L. intestinalis - кишечные паразиты различных рыбоядных птиц, преимущественно чайковых (Определитель..., 1987; Пугачев, 2002). Широко распространен в водоемах Колымского бассейна (Пугачев, 1984; Леонов, Обушенков, 1985; Никишин, Леонов, 2000; Однокурцев, 2015). Как массовый патогенный паразит обнаружен у озерного гольяна (Phoxinus perenurus (Pallas, [1814])) в озерах и старицах p. Тауй Северного Приохотья (Атрашкевич и др., 2005).

7. Schistocephalus solidus (Müller, 1776), pl.

Хозяин: колымский подкаменщик.

Локализация: полость тела.

Голарктический паразит пресноводных рыб, жизненный цикл которого аналогичен таковому предыдущего вида ремнецов. Однако в роли второго промежуточного (дополнительного) хо- зяина $S$. solidus обычно выступают трехиглая колюшка (Gasterosteus aculeatus L., 1758) и некоторые виды пресноводных бычков (Cottidae) (Определитель..., 1987; Пугачев, 2002). В Северном Приохотье плероцеркоиды S. solidus отмечены у трехиглой колюшки в Ольской лагуне Тауйской губы (Атрашкевич и др., 2005).

\section{Отр. Onchoproteocephalidea}

Сем. Proteocephalidae

8. Proteocephalus longicollis (Zeder, 1800)

Хозяин: арктический голец.

Локализация: кишечник.

Широко распространенный в Голарктике кишечный паразит пресноводных рыб, промежуточными хозяевами которого являются различные планктонные ракообразные - копеподы (Пугачев, 2002; Буторина и др., 2011). В Северном Охотоморье отмечен у различных лососевых рыб в пресноводный период жизни (Поспехов и др., 2014).

Proteocephalus sp., juv.

Хозяева: арктический голец, восточносибирский хариус, обыкновенный валек, тонкохвостый налим.

Локализация: кишечник.

Молодые, ювенильные формы цестод рода Proteocephalus - обычные паразиты различных пресноводных рыб Северного Охотоморья, в т. ч. лососевидных (Поспехов и др., 2014, 2020), четкая видовая дифференциация которых представляет известное затруднение.

Класс TREMATODA

Oтр. Diplostomida

Сем. Diplostomidae

9. Diplostomum gavium (Guberlet, 1922), met.

Хозяин: восточносибирский хариус*.

Локализация: стекловидное тело глаз.

Широко распространенный в Голарктике паразит пресноводных рыб, тяготеющий к северным широтам (Пугачев, 2003; Буторина и др., 2011). Личиночное развитие диплостомумов протекает по сложной, единой схеме с участием водных моллюсков в качестве первых и различных пресноводных рыб - в качестве вторых промежуточных хозяев. Облигатные дефинитивные хозяева $D$. gavium - различные виды гагар (Gaviidae). Первый промежуточный хозяин не известен (Пугачев, 2003). Характерный паразит гольцовых рыб Северного Охотоморья (Поспехов и др., 2014). Отмечен также у хариусов, колымского подкаменщика, девятииглой колюшки (Pungitius pungitius (L., 1758)) и других рыб во многих пресных водоемах Тауйского побережья, в т. ч. Эликчанских озерах Северного Приохотья (Атрашкевич и др., 2005; Поспехов и др., 2020).

10. Diplostomum pungitii Shigin, 1965, met.

Хозяева: обыкновенный гольян*, колымский подкаменщик* 

яблока.

Локализация: внутренняя оболочка глазного

Предполагается широкое распространение паразита в водоемах Палеарктики. Первый промежуточный хозяин не известен. Дефинитивными хозяевами $D$. pungitii являются различные рыбоядные и утиные птицы (Определитель..., 1987; Пугачев, 2003). В пресных водоемах Охотоморского побережья впервые отмечен у девятииглой колюшки и колымского подкаменщика (Атрашкевич и др., 2005).

11. Diplostomum pusillum (Dubois, 1928), met.

Хозяева: обыкновенный валек*, колымский подкаменщик*.

Локализация: оболочки глаза (между сосудистой оболочкой и ретиной).

Относительно редкий паразит пресноводных, преимущественно карповых рыб, и обычный кишечный паразит рыбоядных птиц Голарктики (Шигин, 1986; Определитель..., 1987; Пугачев, 2003). Промежуточный хозяин не установлен. Известны находки зрелых трематод у тихоокеанской чайки (Larus schistisagus Stejneger, 1884) и большого крохаля (Mergus merganser L., 1758) на Тауйском побережье Охотского моря (Белогуров, 1965). У рыб Охотско-Колымского края D. pusillum ранее не отмечался.

12. Diplostomum rutili Razmashkin, 1969, met.

Хозяин: колымский подкаменщик* .

Локализация: хрусталик глаза.

Обычный, широко распространенный паразит пресноводных рыб Палеарктики (Пугачев, 2003). Жизненный цикл $D$. rutili хорошо изучен: первые промежуточные хозяева - различные виды брюхоногих моллюсков рода Lymпаеа, а облигатные дефинитивные хозяева - различные чайки и крачки (Шигин, 1986). Отмечен у хариусов и озерного гольяна в водоемах басс. Тауйской губы Охотского моря (Атрашкевич и др., 2005; Поспехов и др., 2020).

13. Diplostomum volvens Nordmann, 1832, met.

Хозяин: колымский подкаменщик.

Локализация: внутренние среды глазного яблока (между склерой и ретиной).

Широко распространенный паразит пресноводных рыб Голарктики, а во взрослом состоянии - облигатный кишечный паразит чайковых птиц, жизненный цикл которого хорошо изучен (Определитель..., 1987; Пугачев, 2003; Буторина и др., 2011). В водоемах басс. Тауйской губы Охотского моря отмечен у хариусов, озерного гольяна, девятииглой колюшки и колымского подкаменщика (Атрашкевич и др., 2005; Поспехов и др., 2020).

Diplostomum spp., met.

Хозяева: обыкновенный валек, обыкновенный гольян.
Локализация: жидкие среды глаза.

Для точной диагностики метацеркарий диплостомумов (заключительной стадии личиночного развития, паразитирующей, как правило, в глазах рыб) по морфологическим данным в основном используется специальная методика А. А. Шигина (1986), требующая прижизненного изучения гельминтов с обязательным условием четкого разделения глазного яблока рыб на структурные составляющие, что не всегда возможно осуществить в полевых условиях. По этой причине указанная методика непосредственно на озерах Дарпир в должной мере в ряде случаев не применялась, поскольку основная цель в отношении этих трематод заключалась в оценке уровня зараженности рыб глазными метацеркариями.

\section{Сем. Strigeidae}

14. Apatemon gracilis (Rudolphi, 1819), met.

Хозяева: восточносибирский хариус*, колымский подкаменщик*.

Локализация: полость тела, на внутренних органах.

Широко распространенный кишечный паразит рыбоядных и водоплавающих птиц, преимущественно утиных Палеарктики, жизненный цикл которого хорошо изучен в европейской части ареала (Пугачев, 2003). Метацеркарии A. gracilis - массовые полостные паразиты колымского подкаменщика и девятииглой колюшки во всех бассейнах рек Северного Приохотья (Атрашкевич и др., 2005).

15. Ichthyocotylurus erraticus (Rudolphi, 1809), met.

Хозяин: обыкновенный гольян.

Локализация: на сердце, печени, кишечнике, почках и гонадах.

Широко распространенный в Голарктике паразит пресноводных, главным образом лососевидных рыб, тяготеющий к северным широтам и относительно хорошо изученный (Судариков, 1984; Определитель..., 1987; Пугачев, 2003; Буторина и др., 2011). Первые промежуточные хозяева трематоды на Чукотке - моллюски Physa lewisi и Valvata helicoidae (Орловская, Атрашкевич, 1989). Облигатные дефинитивные хозяева I. erraticus - различные рыбоядные птицы, в первую очередь гагары, чайки и крачки (Пугачев, 2003). Фоновый, патогенный паразит рыб в пресноводных экосистемах Северного Охотоморья (Орловская, 2003; Атрашкевич и др., 2005; Поспехов и др., 2014, 2020).

16. Ichthyocotylurus pileatus (Rudolphi, 1802), met.

Хозяева: арктический голец*, восточносибирский хариус*, обыкновенный валек, сибирский чукучан*, колымский подкаменщик.

Локализация: на сердце, в перикардиальной полости. 
Общая информация по предыдущему виду относится и к I. pileatus, разве что этот паразит менее изучен и его патогенное воздействие на инвазированных рыб не столь велико. Облигатные дефинитивные хозяева I. pileatus - главным образом чайки и крачки (Пугачев, 2003). Паразит отмечен у рыб Верхнеколымского бассейна (Пугачев, 1984; Никишин, Леонов, 2000), а также в пресноводных экосистемах Северного Охотоморья (Орловская, 2003; Атрашкевич и др., 2005; Поспехов и др., 2014, 2020).

17. Ichthyocotylurus platycephalus (Creplin, 1825), met.

Хозяин: обыкновенный валек*.

Локализация: на сердце, гонадах, почках, стенке плавательного пузыря.

Широко распространенный в Голарктике паразит пресноводных рыб, преимущественно карповых. В числе известных первых промежуточных хозяев этой трематоды - моллюски Valvata sibirica Middendorff, 1851 и $V$. piscinalis (O. F. Müller, 1774). Облигатные дефинитивные хозяева I. platycephalus - преимущественно чайки и крачки (Судариков, 1984; Определитель..., 1987; Пугачев, 2003). Паразит отмечен в Колымском бассейне (Пугачев, 1984), а также у различных непромысловых видов рыб в пресных водоемах побережья Тауйской губы Охотского моря (Атрашкевич и др., 2005).

\section{Отр. Plagiorchiida}

\section{Сем. Allocreadiidae}

18. Allocreadium isoporum (Looss, 1894)

Хозяин: обыкновенный гольян.

Локализация: кишечник.

Широко распространенный паразит пресноводных рыб Палеарктики, жизненный цикл которого хорошо изучен. Первые промежуточные хозяева - моллюски рода Sphaerium, вторые насекомые Ephimera vulgate L., 1758, Anabolia nervosa (Curtis, 1834) (Определитель..., 1987; Пугачев, 2003). В Охотско-Колымском крае A. isoporum обнаружен у пресноводных рыб разных видов (Пугачев, 1984; Леонов, Обушенков, 1985; Никишин, Леонов, 2000; Атрашкевич и др., 2005; Поспехов и др., 2014, 2020).

19. Bunodera sp., ad.

Хозяин: тонкохвостый налим*.

Локализация: кишечник.

Для точной идентификации вида требуется дополнительный материал, поскольку обнаружены только две зрелые трематоды (мариты), отличающиеся от известных представителей рода Bunodera и представляющие несомненный интерес для описания их морфологических особенностей (рис. 2).

Описание. Мелкие трематоды с овальной формой тела и гладким тегументом. Длина тела 808-888, ширина в средней части на уров-

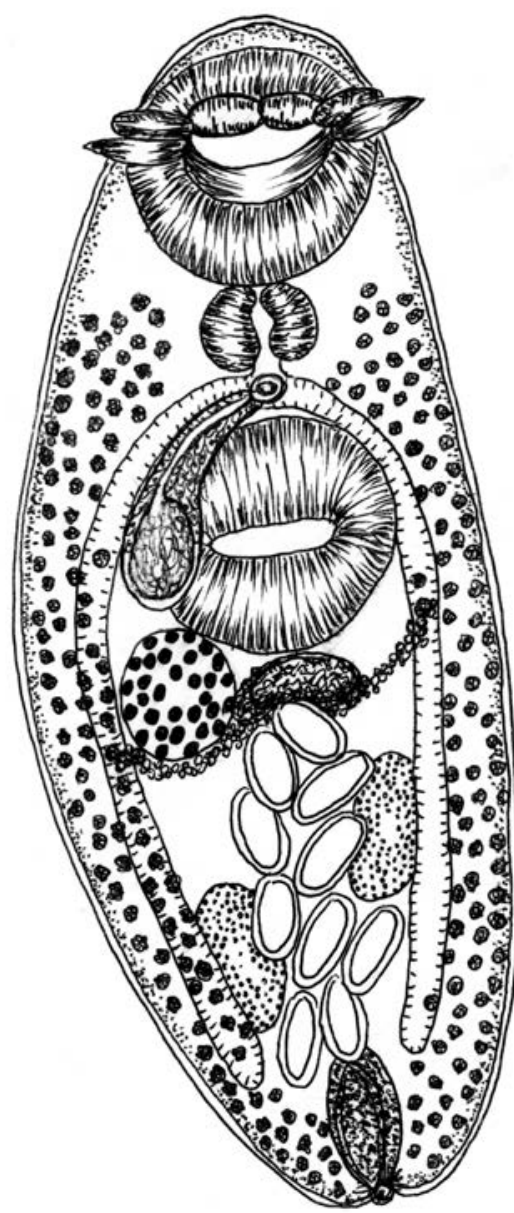

Puc. 2. Bunodera sp., марита. Масштабная линейка 0.3 мм. Оригинал

Fig. 2. Bunodera sp., marita. Scale bar $0.3 \mathrm{~mm}$. Original

не брюшной присоски 331-343. Ротовая присоска округлая, субтерминальная, размером 137$168 \times 153-168$, снабжена шестью мышечными выростами - двумя латерально-вентральными, длиной 51-58 и шириной в средней части $25-28$, с заостренными кончиками, выходящими за пределы присоски, двумя латерально-дорсальными меньшей длины и двумя дорсальными, более короткими и широкими. Префаринкс не обнаружен. Округлый фаринкс, размером 61-76 × 76, прилегает к заднему краю ротовой присоски. Короткий пищевод, длиной 20-22, переходит в бифуркацию кишечника, которая располагается выше брюшной присоски на расстоянии 229-230 от переднего края тела. Кишечные ветви прямые, достигают заднего края тела, где слепо оканчиваются на расстоянии 163 170 от него. Брюшная присоска округлая, размером $152-162 \times 152-168$, находится на расстоянии 102-112 от заднего края ротовой присоски. Крупная половая бурса размером 153-204 × 86-90, имеющая расширенную заднюю часть и доходящая до середины присоски, содержит семенной пузырек и простатическую часть. 
Таблица 2. Состав паразитов и параметры зараженности лососевидных рыб озерно-речной системы Дарпир

Table 2. The parasite fauna and infestation parameters in salmonoid fish from the Darpir lake-river system

\begin{tabular}{|c|c|c|c|c|c|c|c|c|c|}
\hline \multirow{3}{*}{ Классы и виды паразитов } & \multicolumn{9}{|c|}{ Показатели зараженности } \\
\hline & \multicolumn{3}{|c|}{$\begin{array}{l}\text { Salvelinus alpinus complex } \\
\qquad \mathrm{n}=31\end{array}$} & \multicolumn{3}{|c|}{$\begin{array}{l}\text { Thymallus a. pallasi } \\
\mathrm{n}=46\end{array}$} & \multicolumn{3}{|c|}{$\begin{array}{c}\text { Prosopium cylindraceum } \\
\mathrm{n}=23\end{array}$} \\
\hline & ЭИ & ИИ & ИО & ЭИ & ИИ & ИО & ЭИ & ИИ & ИО \\
\hline \multicolumn{10}{|l|}{ CESTODA } \\
\hline Cyathocephalus truncatus & 9.7 & $2-5$ & 0.30 & 39.1 & $1-38$ & 3.00 & \multicolumn{3}{|c|}{-} \\
\hline Eubothrium salvelini & 41.9 & $1-11$ & 1.20 & 6.5 & $1-2$ & 0.90 & \multicolumn{3}{|c|}{-} \\
\hline Dibothriocephalus dendriticus, pl. & 54.8 & $1-13$ & 1.50 & 30.4 & $1-7$ & 0.90 & \multicolumn{3}{|c|}{-} \\
\hline D. ditremus, pl. & 100.0 & $7-135$ & 47.80 & 91.3 & $1-13$ & 2.50 & \multicolumn{3}{|c|}{-} \\
\hline Proteocephalus longicollis & 9.7 & $3-11$ & 0.70 & \multicolumn{3}{|c|}{-} & \multicolumn{3}{|c|}{-} \\
\hline Proteocephalus spp., juv. & 74.2 & $2-153$ & 19.50 & 6.5 & $1-5$ & 0.20 & 4.4 & 1 & 0.04 \\
\hline \multicolumn{10}{|l|}{\begin{tabular}{|l|} 
TREMATODA \\
\end{tabular}} \\
\hline Diplostomum gavium, met. & \multicolumn{3}{|c|}{-} & 6.5 & $3-11$ & 0.41 & \multicolumn{3}{|c|}{-} \\
\hline D. pusillum, met. & \multicolumn{3}{|c|}{-} & \multicolumn{3}{|c|}{-} & 13.0 & $5-13$ & 1.04 \\
\hline Diplostomum spp., met. & \multicolumn{3}{|c|}{-} & \multicolumn{3}{|c|}{-} & 87.0 & $5-33$ & 11.04 \\
\hline Apatemon gracilis, met. & \multicolumn{3}{|c|}{-} & 4.4 & $11 ; 26$ & 0.80 & \multicolumn{3}{|c|}{-} \\
\hline Ichthyocotylurus pileatus, met. & 3.2 & 21 & 0.68 & 2.2 & 12 & 0.26 & 39.1 & $7-24$ & 4.40 \\
\hline I. platycephalus, met. & \multicolumn{3}{|c|}{-} & \multicolumn{3}{|c|}{-} & 4.4 & 10 & 0.44 \\
\hline Crepidostomum farionis & 12.9 & $5-6$ & 0.45 & 47.8 & $1-20$ & 2.70 & 4.4 & 7 & 0.30 \\
\hline C. metoecus & 48.4 & $1-38$ & 6.90 & 89.1 & $1-250$ & 47.70 & 4.4 & 2 & 0.09 \\
\hline Crepidostomum sp., ad. & 3.2 & 1 & 0.03 & \multicolumn{3}{|c|}{-} & & - & \\
\hline Crepidostomum spp., juv. & 19.4 & $2-86$ & 4.00 & 23.9 & $1-57$ & 4.20 & 56.5 & $1-19$ & 3.40 \\
\hline Phyllodistomum folium & 9.7 & 6-152 & 7.52 & 8.7 & $6-80$ & 3.91 & & - & \\
\hline Ph. umblae & 6.5 & $18-27$ & 2.10 & 4.4 & $6 ; 35$ & 0.89 & & - & \\
\hline Phyllodistomum spp., juv. & 3.2 & 27 & 0.87 & 2.2 & 30 & 0.65 & & - & \\
\hline ENOPLEA & & & & & & & & & \\
\hline Pseudocapillaria salvelini & 54.8 & $1-149$ & 25.70 & 67.4 & $3-123$ & 14.10 & 39.1 & $1-7$ & 1.09 \\
\hline CHROMADOREA & & & & & & & & & \\
\hline Ichtyobronema hamulatum & 12.9 & $1-2$ & 0.23 & 4.4 & $1 ; 1$ & 0.04 & & - & \\
\hline Cucullanus truttae & 41.9 & $1-7$ & 1.10 & 17.4 & $1-3$ & 0.40 & & - & \\
\hline Salmonema ephemeridarum & 3.2 & 1 & 0.03 & 4.4 & $1 ; 2$ & 0.07 & & - & \\
\hline Cystidicola farionis & 6.5 & $5 ; 32$ & 1.20 & 19.6 & $1-27$ & 2.10 & & - & \\
\hline PALAEACANTHOCEPHALA & & & & & & & & & \\
\hline Pseudoechinorhynchus borealis & 38.7 & $1-47$ & 3.77 & 73.9 & $1-160$ & 17.28 & & - & \\
\hline EOACANTHOCEPHALA & & & & & & & & & \\
\hline Neoechinorhynchus salmonis & 90.3 & $2-685$ & 142.52 & 67.4 & $1-185$ & 16.35 & 17.4 & $1-4$ & 0.35 \\
\hline N. simansularis & & - & & 10.9 & $1-8$ & 0.28 & & - & \\
\hline N. tumidus & 83.9 & $1-234$ & 16.71 & 32.6 & $1-25$ & 1.94 & 4.4 & 1 & 0.04 \\
\hline CRUSTACEA & & & & & & & & & \\
\hline Salmincola thymalli & & - & & 2.2 & 3 & 0.07 & & - & \\
\hline Salmincola sp. & & - & & & - & & 4.4 & 1 & 0.04 \\
\hline
\end{tabular}

Половое отверстие медианное, располагается впереди брюшной присоски на уровне бифуркации кишечника, на расстоянии 230-236 от переднего края тела. Желточные поля начинаются на уровне фаринкса и доходят до самого конца тела, но не смыкаются, а разделяются экскреторным пузырем. Желточные фолликулы очень мелкие, округлые, размером 15-17, заходят на кишечные ветви. Желточные поля находятся на расстоянии 153-163 от переднего края тела. Округлый яичник размером 86-102 × 7686 , располагается позади брюшной присоски, справа от медианной линии тела. Рядом с яичником находится бобовидный семяприемник размером 68-71 × 51-56. Семенники овальные, цельнокрайные, лежат в задней половине тела по диагонали друг к другу и разделены маткой с яйцами. Передний семенник, размером 86-92 × $102-107$, находится на расстоянии $102-104$ от яичника. Задний семенник, размером 90-96 × 
104-109, лежит на расстоянии 92-98 от переднего. Матка простирается от брюшной присоски до экскреторного пузыря и содержит 11-12 крупных овальных яиц размером 76-78 × 51-53. Экскреторное отверстие терминальное, от него отходит небольшой овальный экскреторный пузырь размером 96-98 × 62-64.

Описываемые трематоды отличаются от других известных видов рода Bunodera следующими признаками: овальной формой тела и отсутствием «шейки» позади ротовой присоски; наличием очень мелких желточных фолликулов; расположением семяприемника; маленьким экскреторным пузырем овальной формы.

20. Crepidostomum farionis (Müller, 1780)

Хозяева: арктический голец, восточносибирский хариус, обыкновенный валек.

Локализация: кишечник.

Широко распространенный, фоновый паразит пресноводных рыб, преимущественно лососевидных Голарктики (Определитель..., 1987; Пугачев, 2003; Буторина и др., 2011). Один из фоновых видов трематод пресноводных рыб ОхотскоКолымского края и Северного Охотоморья (Пугачев, 1984; Никишин, Леонов, 2000; Атрашкевич и др., 2005, 2011; Соколов, 2005; Поспехов и др., 2014, 2020). Жизненный цикл C. farionis в пресных водах Охотско-Колымского края протекает с участием моллюска Sphaerium rectidens Starobogatov et Streletzkaja, 1967 и бокоплава $G$. lacustris в качестве, соответственно, первого и второго промежуточных хозяев (Атрашкевич и др., 2005).

21. Crepidostomum metoecus (Braun, 1900)

Хозяева: арктический голец, восточносибирский хариус, обыкновенный валек*, сибирский чукучан*.

Локализация: желудок, кишечник.

Как и предыдущий вид - широко распространенный, фоновый паразит пресноводных рыб Голарктики (Определитель..., 1987; Пугачев, 2003; Буторина и др., 2011), жизненный цикл которого в Охотско-Колымском крае реализуется, вероятно, аналогично предыдущему виду. C. metoecus обычен, но малочислен у жилых лососевидных рыб басс. Верхней Колымы и Северного Охотоморья (Пугачев, 1984; Никишин, Леонов, 2000; Атрашкевич и др., 2005, 2011; Поспехов и др., 2014, 2020).

\section{Crepidostomum sp., ad.}

Хозяин: арктический голец*.

Локализация: кишечник.

Среди трематод рода Crepidostomum в нашем материале от арктического гольца обнаружен один зрелый экземпляр (марита), отличающийся от известных видов, в т. ч. от двух предыдущих, и представляющий несомненный интерес для его морфологического описания (рис. 3).

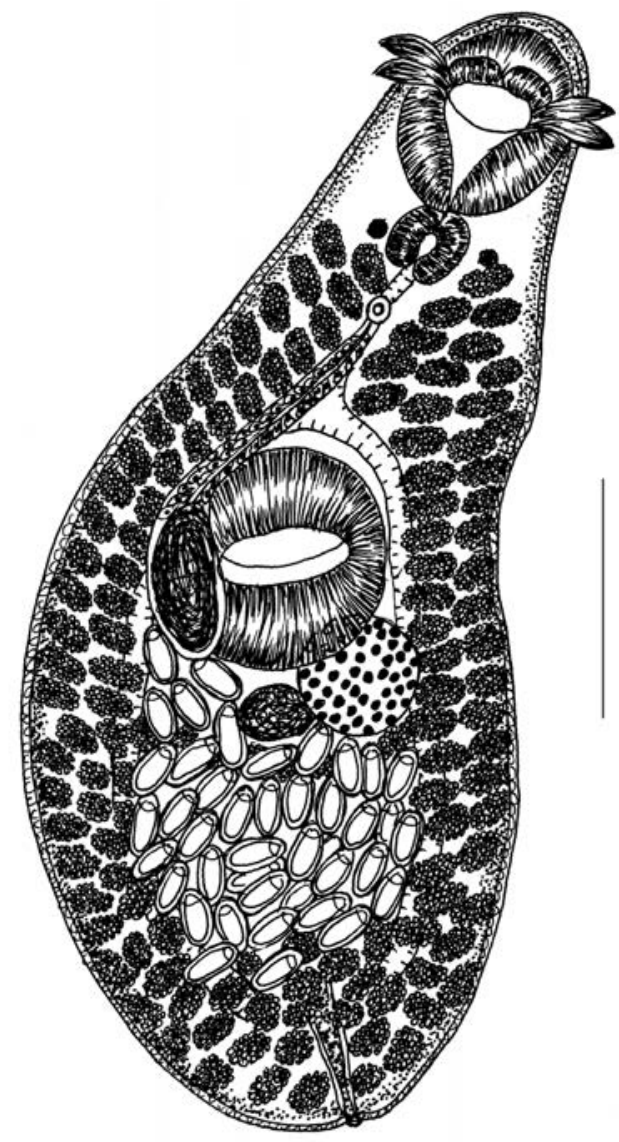

Puc. 3. Crepidostomum sp., марита. Масштабная линейка 0.3 мм. Оригинал

Fig. 3. Crepidostomum sp., marita. Scale bar $0.3 \mathrm{~mm}$. Original

Описание. Мелкая трематода с расширенной второй половиной тела и гладким тегументом. Длина тела 1148, ширина на уровне ротовой присоски 212 и 515 - позади брюшной присоски. Ротовая присоска субтерминальная, овальная, $202 \times$ 161; имеет шесть мышечных выростов: четыре латеральных (по два с каждой стороны присоски) размером $51 \times 20$, удлиненных, с заостренными кончиками, выходящими за пределы ротовой присоски, и два дорсальных выроста - коротких, широких, размером $30 \times 61$. К заднему краю ротовой присоски прилегает округлый фаринкс размером $71 \times 63$, от которого отходит тонкий пищевод длиной 127. По сторонам фаринкса видны два округлых пигментных глазка. Бифуркация кишечника располагается выше брюшной присоски, на расстоянии 408 от переднего края тела. Округлая брюшная присоска диаметром 244 расположена в центре тела трематоды на одинаковом расстоянии от переднего и заднего его концов и на расстоянии 270 от заднего края ротовой присоски. Половая бурса размером $382 \times$ 127 - крупная, длинная, ее расширенный задний конец немного выходит за пределы присоски, со- 
держит крупный семенной пузырек и простатические клетки. Половое отверстие расположено медианно в районе пищевода, ближе к фаринксу, на расстоянии 305 от переднего края тела. Округлый яичник размером $127 \times 112$ лежит слева от медианной линии, позади брюшной присоски, и его конец немного заходит под присоску. Рядом с яичником, медианно находится семяприемник размером $76 \times 61$. Овальные, равновеликие семенники располагаются один позади другого, плотно прикрыты маткой с яйцами и плохо просматриваются. Матка длиной 306, занимает все межкишечное пространство от брюшной присоски и до окончания кишечных ветвей, заполнена крупными овальными яйцами желтого цвета с крышечкой. Матка содержит 42 яйца размером 71-73 × 49-51. Желточные поля состоят из крупных овальных фолликулов размером $61 \times 58$. Они простираются от фаринкса до заднего края тела, где смыкаются позади матки с яйцами. Фолликулы находятся на расстоянии 255 от переднего края тела, плотными рядами тянутся вдоль сторон тела, заходя на кишечные ветви. Экскреторное отверстие терминальное, от него отходит трубковидный экскреторный пузырь, видимая часть которого составляет 178, остальная - скрыта под маткой с яйцами.

Главный отличительный признак описываемой трематоды от всех известных видов рода Crepidostomum - наличие крупной матки, заполняющей все межкишечное пространство от брюшной присоски и до окончания кишечных ветвей. Кроме этого, трематода отличается значительно меньшим размером и грушевидной формой тела, расположением мышечных выростов на ротовой присоске (4 - латеральных и 2 дорсальных), расположением брюшной присоски в центре тела, расположением семяприемника на одном уровне с яичником.

Crepidostomum spp., juv.

Хозяева: арктический голец, восточносибирский хариус, обыкновенный валек, тонкохвостый налим, сибирский чукучан.

Локализация: желудок, кишечник.

Идентифицировать конкретно до вида молодые формы Crepidostomum spp., обнаруженные у рыб пяти видов (у лососевидных - во множестве), кроме обыкновенного гольяна и колымского подкаменщика, не представилось возможным. Это могут быть представители трех, выше обозначенных крепидостомумов, в первую очередь - C. farionis либо C. metoecus.

\section{Сем. Gorgoderidae}

23. Phyllodistomum folium (Olfers, 1816)

Хозяева: арктический голец, восточносибирский хариус.

Локализация: почечные протоки.

Широко распространенный паразит почек и мочевого пузыря различных пресноводных рыб
Палеарктики (Определитель..., 1987; Буторина и др., 2011). В качестве первых промежуточных хозяев трематоды известны двустворчатые моллюски родов Anodonta и Dreissena (Пугачев, 2003). Обнаружен ранее (как P. simile Nybelin, 1926) у камчатского хариуса и колымского подкаменщика в басс. р. Тауй и в качестве фонового паразита - у арктического гольца в Эликчанских озерах басс. р. Яма Северного Охотоморья (Атрашкевич и др., 2005; Поспехов и др., 2020).

24. Phyllodistomum umblae (Fabricius, 1780)

Хозяева: арктический голец, восточносибирский хариус.

Локализация: почечные протоки.

Широко распространенный, специфичный паразит выделительной системы пресноводных рыб, преимущественно лососевых и хариусовых Голарктики (Пугачев, 2003; Буторина и др., 2011). Жизненный цикл P. umblae реализуется с участием моллюсков рода Sphaerium в качестве первых и личинок хирономид рода Procladius вторых промежуточных хозяев (Пугачев, 2003). Обычный, в отдельных водоемах массовый паразит рыб Северо-Востока России, в т. ч. в ОхотскоКолымском крае (Пугачев, 1984; Никишин, Леонов, 2000; Поспехов и др., 2014, 2020). Массовый паразит почек колымского подкаменщика в Эликчанских озерах басс. р. Яма Северного Охотоморья (Атрашкевич и др., 2005).

Phyllodistomum spp., juv.

Хозяева: арктический голец, восточносибирский хариус, сибирский чукучан", колымский подкаменщик.

Локализация: почечные протоки.

Молодые формы рода Phyllodistomum не представилось возможным соотнести с каким-либо из двух выше отмеченных видов.

Тип NEMATODA

Класс ENOPLEA

Отр. Trichinellida

Cем. Capillariidae

25. Pseudocapillaria salvelini (Poljansky, 1952)

Хозяева: арктический голец, восточносибирский хариус, обыкновенный валек, колымский подкаменщик.

Локализация: желудок, кишечник.

Облигатный паразит различных пресноводных рыб в северных и умеренных широтах по всей Голарктике (Пугачев, 2004; Буторина и др., 2011). Один из фоновых видов нематод пресноводных рыб Северо-Востока Азии и ОхотскоКолымского края в частности (Пугачев, 1984; Никишин, Леонов, 2000; Атрашкевич и др., 2005; Поспехов и др., 2014, 2020). Жизненный цикл паразита изучен фрагментарно. Известны экспериментальные данные об участии пресноводных олигохет в качестве промежуточных хозяев P. salvelini. Предполагается участие олигохет и в 
качестве паратенических хозяев нематоды (Пугачев, 2004).

\section{Класс CHROMADOREA \\ Отр. Rhabditida \\ Сем. Quimperiidae} 1931)

26. Ichtyobronema hamulatum (Moulton,

Хозяева: арктический голец*, восточносибирский хариус, тонкохвостый налим.

Локализация: желудок, кишечник.

Широко распространенный в водоемах Голарктики вид, ареал которого совпадает с ареалом налима. Жизненный цикл не изучен (Пугачев, 2004). В бассейне Колымы нематода обнаружена у налима и обыкновенного гольяна (Пугачев, 1984; Леонов, Обушенков, 1985; Однокурцев, 2015). Есть предположение, что роль первых промежуточных хозяев I. hamulatum выполняют бентосные беспозвоночные (Diptera, Ephemeroptera), поскольку рыбы-бентофаги выступают, главным образом, в роли паратенических хозяев нематоды (Пугачев, 2004).

Сем. Cucullanidae

27. Cucullanus truttae Fabricius, 1794

Хозяева: арктический голец, восточносибирский хариус.

Локализация: желудок, кишечник.

Обычный, облигатный паразит реофильных лососевидных пресноводных рыб, жизненный цикл которого хорошо изучен. Широко распространен в Северной Евразии (Пугачев, 2004; Буторина и др., 2011). Один из фоновых паразитов реофильных видов рыб и проходных лососевых Северного Охотоморья (Соколов, 2005; Поспехов и др., 2014, 2020).

\section{Сем. Cystidicolidae}

28. Salmonema ephemeridarum (Linstow, 1872)

Хозяева: арктический голец, восточносибирский хариус.

Локализация: желудок, кишечник.

Широко распространенный в Голарктике, включая Северное Охотоморье (Пугачев, 2004), паразит пищеварительного тракта пресноводных лососевидных рыб (Соколов, 2005; Буторина и др., 2011; Поспехов и др., 2014, 2020). Жизненный цикл нематоды реализуется с участием амфибиотических насекомых в качестве промежуточных хозяев, а рыб - как паратенических и постциклических хозяев (Пугачев, 2004).

29. Cystidicola farionis Fischer, 1798

Хозяева: арктический голец, восточносибирский хариус.

Локализация: плавательный пузырь.

Широко распространенный, облигатный паразит плавательного пузыря лососевых, хариусовых, сиговых, корюшковых и тресковых рыб в озерах и приустьевых участках рек Голарктики (Margolis, Arthur, 1979; Определитель..., 1987; Пугачев, 2004; Буторина и др., 2011). Жизненный цикл протекает с участием бокоплавов и мизид в качестве промежуточных хозяев. В оз. Кроноцкое на Камчатке промежуточным хозяином нематоды является бокоплав G. lacustris (Соколов, Гордеев, 2014). Этот же вид бокоплава обнаружен нами в желудках рыб четырех видов, в т. ч. восточносибирского хариуса, и, очевидно, также служит промежуточным хозяином C. farionis в озерах Дарпир.

\section{Тип ACANTHOCEPHALES}

Класс PALAEACANTHOCEPHALA

Отр. Echinorhynchida

Cем. Echinorhynchidae 1901)

30. Pseudoechinorhynchus borealis (Linstow,

Хозяева: арктический голец, восточносибирский хариус, тонкохвостый налим, сибирский чукучан*, обыкновенный гольян, колымский подкаменщик.

Локализация: желудок, кишечник.

Широко распространенный в водоемах Палеарктики вид, о таксономическом статусе которого среди специалистов по-прежнему нет единого мнения (Определитель..., 1987; Пугачев, 2004; Amin et al., 2015; Wayland et al., 2015; Reier et al., 2020), и наша позиция на этот счет отражена ранее (Атрашкевич и др., 2016). P. borealis - обычный, в отдельных регионах массовый паразит пресноводных рыб Северной Азии (Определитель..., 1987; Балданова, Пронин, 2001; Пугачев, 2004; Атрашкевич и др., 2016). Промежуточные хозяева - различные гаммариды, в т. ч. реликтовые - Pontoporeia affinis Lundstrom, 1855 и Pallasea quadrispinosa G. O. Sars, 1867 (Определитель..., 1987). В этом плане выделяется оз. Байкал, в экосистеме которого роль промежуточных хозяев в жизненном цикле $P$. borealis выполняют эндемичные бокоплавы восьми видов (Балданова, Пронин, 2001). Вероятно, промежуточным хозяином $P$. borealis в озерах Дарпир может быть бокоплав $G$. lacustris, обнаруженный в желудках рыб четырех видов, в т. ч. тонкохвостого налима и колымского подкаменщика. При характеристике распространения P. borealis в пределах CCCP подчеркивается особенно высокая зараженность паразитом налима и бычков-подкаменщиков в Балтийской провинции и Циркумполярной подобласти (Определитель..., 1987). У рыб материкового побережья Охотского моря, как и всего Охотско-Колымского края, P. borealis до сего времени не отмечался. Сибирский чукучан - новый дефинитивный хозяин паразита.

Класс EOACANTHOCEPHALA

Отр. Neoechinorhynchida

Сем. Neoechinorhynchidae 
31. Neoechinorhynchus salmonis Ching, 1984

Хозяева: арктический голец*, восточносибирский хариус, обыкновенный валек*, тонкохвостый налим*, сибирский чукучан*, обыкновенный гольян, колымский подкаменщик*.

Локализация: желудок, кишечник.

Типичный для Азиатской Субарктики амфиберингийский паразит лососевидных рыб, достигающий высокой численности в локальных популяциях планктоноядных видов (Буторина и др., 2011; Михайлова, 2015; Атрашкевич и др., 2016). При этом в составе дефинитивных хозяев N. salmonis отмечены представители и других таксономических групп - щука (Esox lucius L., 1758), колюшки, подкаменщики (Михайлова и др., 2004; Поспехов и др., 2014). Промежуточный хозяин скребня - остракода Cypria kolymensis Akatova, 1975 - впервые установлен в тундровых водоемах Чаунской низменности Чукотки (Михайлова и др., 2004; Михайлова, 2015). Без сомнения, скребень $N$. salmonis является фоновым сочленом в паразитоценозе озер Дарпир, инвазируя все виды обитающих там рыб. 1961

32. Neoechinorhynchus simansularis Roytman,

Хозяева: восточносибирский хариус*, тонкохвостый налим*, сибирский чукучан*, обыкновенный гольян*, колымский подкаменщик*.

Локализация: желудок, кишечник.

Основная часть ареала скребня находится в басс. p. Амур, где наиболее частыми его дефинитивными хозяевами выступают карповые рыбы и ленок (Михайлова, 2015). Положение вида остается спорным и нуждается в выяснении (Пугачев, 2004). Е. С. Скрябина (1978) не признала видовой статус скребня и свела его в синонимы $N$. rutili. О. Амин (Amin, 2002) подтвердил валидность вида, отметив его характерные морфологические особенности. $N$. simansularis обозначается нами как редкий и малочисленный в северных районах паразит рыб, обнаруженный пока лишь в некоторых водоемах басс. Верхней Колымы (Атрашкевич и др., 2016), где основным хозяином скребня отмечен озерный гольян, населяющий малые старицы, и где впервые установлен его промежуточный хозяин - остракода Candona protzi Hartwig, 1898 (Михайлова, 2015). В горных озерах Дарпир N. simansularis - обычный сочлен паразитоценоза, где все виды дефинитивных хозяев являются новыми для паразита.

33. Neoechinorhynchus tumidus Van Cleave et Bangham, 1949

Хозяева: арктический голец, восточносибирский хариус, обыкновенный валек*, сибирский чукучан*, колымский подкаменщик*.

Локализация: желудок, кишечник.

Ранее существовало представление о присутствии паразита в пресных водах северных районов Голарктики (Петроченко, 1956; Bauer, 1970). Итогом ревизии скребней рода Neoechinorhynchus, проведенной Е. С. Скрябиной (1978) по материалам из Российской Субарктики, стало отнесение $N$. tumidus в синонимы $N$. crassus, что закрепилось в отечественной литературе (Определитель..., 1987; Пугачев, 2004), но не было поддержано в Северной Америке (Arai, 1989; Hoffman, 1999; Amin, 2002). В настоящее время восстановлена валидность вида $N$. tumidus для фауны России и обосновано его широкое распространение по горным водоемам Северной Азии от Чукотки и басс. Колымы до Забайкалья и Западной Сибири (Михайлова, 2015, 2020; Атрашкевич и др., 2016). Можно полагать, что N. tumidus обычен в жилых популяциях арктических гольцов, населяющих озера Колымского нагорья, имеющих сток в Ледовитоморский бассейн, и обнаружен у арктических гольцов в оз. Хадды и Мак-Мак Охотоморского бассейна. Промежуточные хозяева скребня не известны, но есть предположение, что ими могут быть планктонные веслоногие ракообразные (Михайлова, 2020).

Тип ARTHROPODA

Класс CRUSTACEA

Отр. Siphonostomatoida

Сем. Lernaeopodidae

34. Salmincola thymalli (Kessler, 1868)

Хозяин: восточносибирский хариус.

Локализация: жаберные лепестки.

Специфичный, облигатный паразит хариусов в водоемах Голарктики, в т. ч. в различных районах Северо-Востока Азии (Определитель..., 1987; Пугачев, 2004; Поспехов и др., 2020). В озерах Дарпир $S$. thymalli - редкий и малочисленный паразит рыб.

\section{Salmincola sp.}

Хозяин: обыкновенный валек.

Локализация: жаберные лепестки.

Обнаруженный экземпляр паразитической копеподы имеет некоторое сходство с S. thymalli, однако из-за его повреждения (отсутствует булла) однозначно установить видовую принадлежность паразита не представилось возможным. У обыкновенного валька р. Лена из паразитических копепод отмечен $S$. jacuticus (Однокурцев, 2015), а в р. Анадырь - S. coregonorum (Пугачев, 1984).

Таким образом, фауна паразитов рыб горных озер Б. и М. Дарпир представлена 34 видами 33 видами гельминтов и одним видом паразитических копепод (22 рода, 16 семейств, 12 отрядов, 7 классов, 4 типа - Plathelminthes, Nematoda, Acanthocephales, Arthropoda). По числу видов среди гельминтов полностью доминируют трематоды - 16 (7 родов, 4 семейства, 2 отряда); вдвое меньше цестод -8 видов (7 родов, 5 семейств, 5 отрядов) и далее следуют нематоды - 5 видов (5 родов, 4 семейства, 2 отряда, 
2 класса) и скребни - 4 вида (2 рода, 2 семейства, 2 отряда, 2 класса).

Для 17 видов гельминтов (11 видов трематод, 4 - скребней, 1 - цестод и 1 - нематод) установлены новые хозяева из числа всех семи исследованных видов рыб. В этом отношении выделяются сибирский чукучан и колымский подкаменщик как новые хозяева для 8 и 7 видов гельминтов соответственно. Далее следуют обыкновенный валек (для 5 видов), восточносибирский хариус (для 4 видов), арктический голец и тонкохвостый налим (для 3 видов каждый) и обыкновенный гольян (для 2 видов).

Поскольку озера Б. и М. Дарпир не изолированы друг от друга и количество исследованных в них рыб каждого вида несоразмерно (кроме восточносибирского хариуса), то, наряду с видовым составом их паразитов, в табл. 2-4 приводятся общие показатели зараженности рыб в этой озерно-речной системе.

По таксономическому разнообразию паразитов и относительно высоким показателям зараженности в целом выделяются лососевидные рыбы. Наибольшее число видов паразитов (22) обнаружено у восточносибирского хариуса (сем. Хариусовые): 5 видов цестод, включая ювенильные формы рода Proteocephalus; 7 видов трематод; 5 видов нематод; 4 вида скребней и 1 вид паразитических копепод. Соразмерное число видов паразитов (19) найдено у арктического гольца (сем. Лососевые): 5 видов цестод, 6 видов трематод; 5 видов нематод и 3 вида скребней. Обыкновенный валек (сем. Сиговые) из этой группы рыб отличается обедненной паразитофауной - 10 видов, с учетом 1 экз. ювенильной Proteocephalus sp. и 1 экз. копеподы Salmincola sp. (см. табл. 2).

Менее разнообразны паразиты других исследованных рыб: колымского подкаменщика (13 видов с учетом ювенильных трематод Phyllodistomum spp.), сибирского чукучана (9 видов с учетом ювенильных трематод Phyllodistomum spp.), обыкновенного гольяна (7 видов) и тонкохвостого налима (7 видов с учетом ювенильных цестод Proteocephalus sp. и трематод Crepidostomum spp.) (см. табл. 3).

\section{Таблица 3. Состав паразитов и параметры зараженности других рыб озерно-речной системы Дарпир}

Table 3. The parasite fauna and parameters of infestation in other fish species from the Darpir lake-river system

\begin{tabular}{|c|c|c|c|c|c|c|c|c|c|c|c|c|}
\hline \multirow{3}{*}{ Классы и виды паразитов } & \multicolumn{12}{|c|}{ Показатели зараженности } \\
\hline & \multicolumn{3}{|c|}{$\begin{array}{l}\text { Lota l. leptura } \\
\qquad \mathrm{n}=8\end{array}$} & \multicolumn{3}{|c|}{$\begin{array}{c}\text { Catostomus } c . \\
\text { rostratus } \\
\mathrm{n}=25\end{array}$} & \multicolumn{3}{|c|}{$\begin{array}{l}\text { Phoxinus phoxinus } \\
\mathrm{n}=43\end{array}$} & \multicolumn{3}{|c|}{$\begin{array}{l}\text { Cottus kolymensis } \\
\qquad \mathrm{n}=12\end{array}$} \\
\hline & ЭИ & ИИ & ИО & ЭИ & ИИ & ИО & ЭИ & ИИ & ИО & ЭИ & ИИ & ИО \\
\hline \multicolumn{13}{|l|}{ CESTODA } \\
\hline Glaridacris catostomi & \multicolumn{3}{|c|}{-} & 52.0 & $1-8$ & 1.60 & \multicolumn{3}{|c|}{-} & \multicolumn{3}{|c|}{-} \\
\hline Ligula intestinalis, $\mathrm{pl}$. & \multicolumn{3}{|c|}{-} & \multicolumn{3}{|c|}{-} & 37.2 & $1-2$ & 0.49 & \multicolumn{3}{|c|}{-} \\
\hline Schistocephalus solidus, pl. & \multicolumn{3}{|c|}{-} & \multicolumn{3}{|c|}{-} & \multicolumn{3}{|c|}{-} & 16.7 & $1 ; 2$ & 0.25 \\
\hline $\begin{array}{l}\text { Dibothriocephalus ditremus, } \\
\text { pl. }\end{array}$ & \multicolumn{3}{|c|}{-} & 4.0 & 1 & 0.04 & \multicolumn{3}{|c|}{-} & \multicolumn{3}{|c|}{-} \\
\hline Proteocephalus sp., juv. & 1 экз. & 12 & 1.50 & \multicolumn{3}{|c|}{-} & \multicolumn{3}{|c|}{-} & \multicolumn{3}{|c|}{-} \\
\hline \multicolumn{13}{|l|}{ TREMATODA } \\
\hline Diplostomum pungiti, met. & \multicolumn{3}{|c|}{-} & \multicolumn{3}{|c|}{-} & 7.0 & $2-17$ & 0.54 & 8.3 & 21 & 1.75 \\
\hline Diplostomum pusillum, met. & \multicolumn{3}{|c|}{-} & \multicolumn{3}{|c|}{-} & \multicolumn{3}{|c|}{-} & 8.3 & 50 & 4.17 \\
\hline Diplostomum rutili, met. & \multicolumn{3}{|c|}{-} & \multicolumn{3}{|c|}{-} & & - & & 16.7 & $1-2$ & 0.25 \\
\hline Diplostomum volvens, met. & & - & & & - & & & - & & 16.7 & $7-76$ & 6.92 \\
\hline Diplostomum spp., met. & & - & & & - & & 51.2 & $1-4$ & 1.40 & & - & \\
\hline Apatemon gracilis, met. & & - & & & - & & & - & & 50.0 & $1-132$ & 14.92 \\
\hline Ichthyocotylurus erraticus, met. & & - & & & - & & 37.2 & $1-6$ & 1.00 & & - & \\
\hline I. pileatus, met. & & - & & 4.0 & 1 & 0.04 & & - & & 16.7 & $10-45$ & 5.75 \\
\hline Allocreadium isoporum & & - & & & - & & 32.6 & $1-6$ & 0.60 & & - & \\
\hline Bunodera sp., ad. & 1 экз. & - & 0.25 & & - & & & - & & & - & \\
\hline Crepidostomum metoecus & & - & & 4.0 & 4 & 0.16 & & - & & & - & \\
\hline Crepidostomum spp., juv. & 1 эКз. & 1 & 0.13 & 4.0 & - & - & & - & & & - & \\
\hline Phyllodistomum spp., juv. & & - & & 4.0 & 3 & 0.12 & & - & & 16.7 & $11-17$ & 2.33 \\
\hline ENOPLEA & & & & & & & & & & & & \\
\hline Pseudocapillaria salvelini & & - & & & - & & & - & & 8.3 & 1 & 0.08 \\
\hline
\end{tabular}


Окончание табл. 3

\begin{tabular}{|c|c|c|c|c|c|c|c|c|c|c|c|c|}
\hline \multirow{3}{*}{ Классы и виды паразитов } & \multicolumn{12}{|c|}{ Показатели зараженности } \\
\hline & \multicolumn{3}{|c|}{$\begin{array}{l}\text { Lota l. leptura } \\
\qquad \mathrm{n}=8\end{array}$} & \multicolumn{3}{|c|}{$\begin{array}{c}\text { Catostomus c. } \\
\text { rostratus } \\
\mathrm{n}=25\end{array}$} & \multicolumn{3}{|c|}{$\begin{array}{l}\text { Phoxinus phoxinus } \\
\mathrm{n}=43\end{array}$} & \multicolumn{3}{|c|}{$\begin{array}{l}\text { Cottus kolymensis } \\
\qquad \mathrm{n}=12\end{array}$} \\
\hline & ЭИ & ИИ & ИО & ЭИ & ИИ & ИО & ЭИ & ИИ & ИО & ЭИ & ИИ & ИО \\
\hline \multicolumn{13}{|l|}{ CHROMADOREA } \\
\hline Ichtyobronema hamulatum & 3 экз. & $2-50$ & 8.25 & \multicolumn{3}{|c|}{-} & \multicolumn{3}{|c|}{-} & \multicolumn{3}{|c|}{-} \\
\hline \multicolumn{13}{|l|}{ PALAEACANTHOCEPHALA } \\
\hline Pseudoechinorhynchus borealis & 8 эКз. & 19-386 & 193.50 & 40.0 & $1-6$ & 1.20 & 2.4 & 1 & 0.23 & 58.3 & $1-20$ & 3.41 \\
\hline \multicolumn{13}{|l|}{ EOACANTHOCEPHALA } \\
\hline Neoechinorhynchus salmonis & 3 экз. & $13-36$ & 8.75 & 20.0 & $1-4$ & 0.36 & 37.2 & $1-13$ & 0.94 & 25.0 & $3-64$ & 5.92 \\
\hline N. simansularis & 3 экз. & $1-3$ & 0.14 & 24.0 & $3-21$ & 1.88 & 23.3 & $1-2$ & 0.33 & 8.3 & 1 & 0.08 \\
\hline N. tumidus & \multicolumn{3}{|c|}{-} & 4.0 & 1 & 0.04 & & - & & 8.3 & 1 & 0.08 \\
\hline
\end{tabular}

Гельминты 13 видов (9 видов трематод и 4 вида цестод) паразитируют на рыбах исключительно в личиночном состоянии, завершая свое развитие в птицах - облигатных дефинитивных хозяевах, связанных с водной средой, биоразнообразие которых в экосистеме Дарпирской впадины отличается самобытностью (Андреев и др., 2020).

Из 16 видов трематод представители 10 видов четырех родов, паразитирующие в органах и тканях рыб, способны оказывать на них известное патогенное воздействие. Это личиночные формы (метацеркарии) рода Diplostomum паразиты глаз (D. gavium, D. pusillum, D. pungitii, $D$. rutili, $D$. volvens), рода Apatemon и Ichthyocotylurus - паразиты внутренних органов (A. gracilis, I. erraticus, I. pileatus ), а также мариты рода Phyllodistomum (P. folium, P. umblae) - паразиты почечных проток рыб. Среди 8 видов цестод есть четыре редких, обнаруженных у рыб одного вида, но с относительно высокими показателями зараженности. В первую очередь, это G. catostomiспецифичный кишечный паразит сибирского чукучана; кишечная цестода $P$. longicollis, обнаруженная у арктического гольца; плероцеркоиды $L$. intestinalis и $S$. solidus - патогенные полостные паразиты обыкновенного гольяна и колымского подкаменщика соответственно. К фоновым паразитам арктического гольца и восточносибирского хариуса относятся пять видов: кишечные цестоды рода Proteocephalus sp., juv. (в т. ч. P. longicollis), E. salvelini и C. truncatus, а также массовые тканевые $D$. dendriticus и $D$. ditremus, личиночные формы которых (плероцеркоиды) локализуются на желудочно-кишечном тракте рыб и имеют признанное медико-ветеринарное значение (в первую очередь $D$. dendriticus).

Три (P. salvelini, C. truttae, C. farionis) из пяти видов нематод относятся к числу фоновых, массовых паразитов, главным образом, лососевидных рыб.

Скребни представлены всего лишь четырьмя видами двух классов, однако из всех групп и ви- дов паразитов они выделяются наиболее широким кругом хозяев в озерах Дарпир, демонстрируя при этом относительно высокие показатели их зараженности: один из них и единственный из всей паразитофауны - $N$. salmonis, является общим для всех семи видов рыб; P. borealis инвазирует рыб шести видов, за исключением обыкновенного валька, а $N$. tumidus и $N$. simansularis встречаются у рыб пяти видов каждый.

Озера Б. и М. Дарпир, отличающиеся по площади и глубине, соединяются между собой 4-километровой протокой, и, естественно, возникает вопрос о степени самобытности их паразитоценозов. В этом плане представляет интерес для сравнения наиболее богатая фауна паразитических червей восточносибирского хариуса (22 вида), исследованного в минимально достаточном количестве в каждом из озер (см. табл. 4).

Несмотря на различие в количестве исследованных хариусов из оз. Б. Дарпир и М. Дарпир, вырисовывается ряд особенностей в распространении отдельных групп и видов паразитов и характере зараженности ими в каждом из озер.

16 из 22 видов паразитов отмечены у хариусов в обоих озерах и только 6 - в каком-либо одном из них. Среди последних 5 видов (I. pileatus, I. hamulatum, C. farionis, $N$. simansularis, $S$. thymalli) обнаружены только в оз. Б. Дарпир и лишь один ( $S$. ephemeridarum) - в оз. М. Дарпир. Как правило, это редкие, единичные паразиты, за исключением нематоды плавательного пузыря рыб C. farionis и скребня $N$. simansularis.

Bсе 7 видов цестод практически в одинаковой мере встречаются в обоих озерах, но наиболее высокие показатели зараженности при этом демонстрируют три из них - оба вида лентецов рода Dibothriocephalus и патогенный паразит пилорических придатков кишечника C. truncatus. Сходная картина вырисовывается и в отношении 7 видов трематод, из которых 6 встречаются у хариусов в обоих озерах, однако к числу массовых паразитов из них относятся 2 вида рода Crepidostomum и патогенный паразит почек P. folium. 
Таблица 4. Состав паразитов и параметры зараженности восточносибирского хариуса в оз. Большой и Малый Дарпир

Table 4. The parasite fauna and parameters of infestation in the East Siberian grayling Thymallus arcticus pallasi from lakes Bolshoy and Maly Darpir

\begin{tabular}{|c|c|c|c|c|c|c|}
\hline \multirow{4}{*}{ Классы и виды паразитов } & \multicolumn{6}{|c|}{ Thymallus a. pallasi } \\
\hline & \multicolumn{3}{|c|}{$\begin{array}{c}\text { Оз. Большой Дарпир } \\
\mathrm{n}=30 \\
\end{array}$} & \multicolumn{3}{|c|}{$\begin{array}{c}\text { Оз. Малый Дарпир } \\
\mathrm{n}=16 \\
\end{array}$} \\
\hline & \multicolumn{6}{|c|}{ Показатели зараженности } \\
\hline & ЭИ & ИИ & ИО & ЭИ & ИИ & ИО \\
\hline \multicolumn{7}{|l|}{ CESTODA } \\
\hline Cyathocephalus truncatus & 53.3 & $1-38$ & 4.07 & 18.8 & $1-11$ & 1.06 \\
\hline Eubothrium salvelini & 3.3 & 1 & 0.03 & 18.8 & $1-2$ & 0.25 \\
\hline Dibothriocephalus dendriticus, pl. & 26.7 & $1-4$ & 0.37 & 43.8 & $1-7$ & 1.63 \\
\hline D. ditremus, $\mathrm{pl}$. & 76.7 & $1-13$ & 3.00 & 75.0 & $1-6$ & 2.00 \\
\hline Proteocephalus spp., juv. & 6.7 & $1 ; 5$ & 0.20 & 6.3 & 1 & 0.06 \\
\hline \multicolumn{7}{|l|}{ TREMATODA } \\
\hline Phyllodistomum umblae & 3.3 & 35 & 1.17 & 6.3 & 6 & 0.38 \\
\hline Apatemon gracilis., met. & 3.3 & 26 & 0.87 & 6.3 & 11 & 0.69 \\
\hline Ichthyocotylurus pileatus, met. & 3.3 & 12 & 0.40 & \multicolumn{3}{|c|}{-} \\
\hline Crepidostomum farionis & \multicolumn{3}{|c|}{$++^{1}$} & \multicolumn{3}{|c|}{++} \\
\hline C. metoecus & \multicolumn{3}{|c|}{++} & \multicolumn{3}{|c|}{++} \\
\hline Phyllodistomum folium & \multicolumn{3}{|c|}{++} & \multicolumn{3}{|c|}{++} \\
\hline Diplostomum gavium, met. & \multicolumn{3}{|c|}{$++^{2}$} & \multicolumn{3}{|c|}{+} \\
\hline \multicolumn{7}{|l|}{ ENOPLEA } \\
\hline Pseudocapillaria salvelini & 60.0 & $5-57$ & 8.87 & 87.5 & $3-123$ & 25.75 \\
\hline \multicolumn{7}{|l|}{ CHROMADOREA } \\
\hline Ichtyobronema hamulatum & 6.7 & $1 ; 1$ & 0.07 & \multicolumn{3}{|c|}{-} \\
\hline Cucullanus truttae & 26.7 & $1-3$ & 0.57 & 6.3 & 1 & 0.06 \\
\hline Salmonema ephemeridarum & \multicolumn{3}{|c|}{-} & 12.5 & $1 ; 2$ & 0.19 \\
\hline Cystidicola farionis & 30.0 & $1-27$ & 3.27 & \multicolumn{3}{|c|}{-} \\
\hline \multicolumn{7}{|l|}{ PALAEACANTHOCEPHALA } \\
\hline Pseudoechinorhynchus borealis & 73.3 & $1-160$ & 19.7 & 75.0 & $2-36$ & 9.69 \\
\hline \multicolumn{7}{|l|}{ EOACANTHOCEPHALA } \\
\hline Neoechinorhynchus salmonis & 73.3 & $2-65$ & 15.83 & 18.8 & $1-185$ & 7.56 \\
\hline N. simansularis & 16.7 & $1-8$ & 0.40 & \multicolumn{3}{|c|}{-} \\
\hline N. tumidus & 13.3 & $1-25$ & 0.33 & 6.3 & 5 & 0.31 \\
\hline \multicolumn{7}{|l|}{ CRUSTACEA } \\
\hline Salmincola thymalli & 3.3 & 3 & 0.10 & \multicolumn{3}{|c|}{-} \\
\hline
\end{tabular}

Из 5 видов нематод только 2 отмечаются у хариусов в обоих озерах, но лишь один - P. salvelini может характеризоваться в качестве массового паразита. Особый интерес вызывают скребни, представленные 4 видами двух классов, из которых $N$. simansularis и $N$. tumidus можно отнести к числу малочисленных, а P. borealis и N. salmonis - к обычным, фоновым сочленам паразитоценоза хариусов в озерах Дарпир.

Отмеченные особенности распространения паразитов у хариусов в каждом из озер Дарпир можно связать как с площадью их акваторий и глубинами, так и с таксономическим составом и биотопическим размещением населяющих их планктонных и бентосных беспозвоночных, слу- жащих промежуточными хозяевами гельминтов. В качестве иллюстрации можно отметить гельминтов пяти видов четырех классов (цестоду $C$. truncatus, трематод $C$. farionis и $C$. metoecus, нематоду C. farionis и скребня P. borealis), жизненные циклы которых реализуются с обязательным участием бокоплавов в качестве промежуточных хозяев. В озерах Дарпир это, скорее всего, $G$. lacustris, обнаруженный нами в желудках 4 видов рыб (см. таксономический список). И если скребень P. borealis и трематоды рода Crepidostomum, без сомнения, являются фоновыми, массовыми паразитами хариуса во всей системе озер Дарпир, то меньшую встречаемость C. truncatus в оз. М. Дарпир и полное отсутствие в нем C. fari- 
onis не представляется возможным объяснить только меньшим количеством исследованных хариусов. Дополнительные материалы (в первую очередь, сведения о промежуточных хозяевах фоновых видов гельминтов, отмеченных в данной работе) авторы надеются получить при паразитологическом изучении рыб из других озер Дарпирской впадины и Омулевского бассейна Верхней Колымы в целом.

\section{ЗАКЛЮЧЕНИЕ}

Исследованная фауна паразитов рыб 7 видов в горных озерах Большой и Малый Дарпир отрогов хр. Черского характеризуется относительно высоким таксономическим и экологическим разнообразием. Выявлены 34 вида паразитов 33 вида гельминтов и 1 вид паразитических копепод (22 рода, 16 семейств, 12 отрядов, 7 классов, 4 типа - Plathelminthes, Nematoda, Acanthocephales, Arthropoda). По числу видов среди гельминтов полностью доминируют трематоды - 16 (7 родов, 4 семейства, 2 отряда); вдвое меньше цестод -8 видов (7 родов, 5 семейств, 5 отрядов) и далее следуют нематоды - 5 видов (5 родов, 4 семейства, 2 отряда, 2 класса) и скребни - 4 вида (2 рода, 2 семейства, 2 отряда, 2 класса).

Наибольшим разнообразием паразитов выделяются фоновые виды лососевидных в озерах Дарпир - восточносибирский хариус (22 вида) и арктический голец (19 видов). Далее по числу видов паразитов располагаются колымский подкаменщик (13 видов), обыкновенный валек (10 видов), сибирский чукучан (9 видов), тонкохвостый налим и обыкновенный гольян (по 7 видов).

Лишь один из 34 видов паразитов - скребень Neoechinorhynchus salmonis, является общим для всех исследованных рыб при высоких показателях зараженности. На второй позиции также многочисленный скребень - Pseudoechinorhynchus borealis, не обнаруженный только у обыкновенного валька, - впервые отмечен у рыб ОхотскоКолымского края и у сибирского чукучана как нового дефинитивного хозяина.

Для 17 видов гельминтов (11 видов трематод, 4 - скребней, 1 - цестод и 1 - нематод) установлены новые хозяева из числа всех семи исследованных видов рыб. В этом отношении выделяются сибирский чукучан и колымский подкаменщик как новые хозяева для 8 и 7 видов гельминтов соответственно. Далее следуют обыкновенный валек (для 5 видов), восточносибирский хариус (для 4 видов), арктический голец и тонкохвостый налим (для 3 видов каждый) и обыкновенный гольян (для 2 видов).

Паразиты 16 из 22 видов отмечены у хариусов в обоих озерах и только 6 - в каком-либо одном из них. Среди последних 5 видов (I. pileatus, I. hamulatum, C. farionis, $N$. simansularis, S. thymalli) обнаружены только в оз. Б. Дарпир и лишь один (S. ephemeridarum) - в оз. М. Дарпир. Как правило, это редкие, единичные паразиты, за исключением нематоды плавательного пузыря рыб C. farionis и скребня $N$. simansularis.

Bce 7 видов цестод практически в одинаковой мере встречаются в обоих озерах, но наиболее высокие показатели зараженности при этом демонстрируют три из них - оба вида лентецов рода Dibothriocephalus и патогенный паразит пилорических придатков кишечника C. truncatus. Сходная картина вырисовывается и в отношении семи видов трематод, из которых шесть встречаются у хариусов в обоих озерах, однако к числу массовых паразитов из них относятся два вида рода Crepidostomum и патогенный паразит почек $P$. folium. Из пяти видов нематод только два встречаются у хариусов в обоих озерах, но лишь один P. salvelini - может характеризоваться в качестве массового паразита. Особый интерес вызывают скребни, представленные четырьмя видами двух классов, из которых $N$. simansularis и $N$. tumidus можно отнести к числу малочисленных, а $P$. borealis и $N$. salmonis - к обычным, фоновым сочленам паразитоценоза хариусов в озерах Дарпир.

Выявленные различия в распространения видов паразитов у хариусов в оз. Большой и Малый Дарпир можно связать как с площадью их акваторий и глубинами, так и с таксономическим составом и биотопическим размещением населяющих их планктонных и бентосных беспозвоночных, служащих промежуточными хозяевами гельминтов.

Авторы выражают благодарность К. В. Регель (ИБПС ДВО РАН) за определение озерных бокоплавов.

Исследования проведены в ходе выполнения государственного задания по теме «Таксономическое, морфологическое и экологическое разнообразие гельминтов позвоночных животных Северной Азии» № АAА-A17-117012710031-6 (ИБПС ДВО РАН) и гранта Русского географического общества 2018 г. по проекту «Озерно-речные системы высокогорных ледниковых равнин криолитозоны».

\section{ЛИТЕРАТУРА}

Андреев А. В., Слободин С. Б., Хаменкова Е. В. Беспощадное освоение Колымы, последний рубеж южная часть хребта Черского // Природа. 2020. № 6. C. 32-45. DOI:10.7868/S0032874X20060046

Атрашкевич Г. И., Михайлова Е. И., Орловская O. М., Поспехов В. В. Биоразнообразие скребней рыб пресных вод Азиатской Субарктики // Паразитология. 2016. Т. 50. Вып. 4. С. 263-290.

Атрашкевич Г. И., Орловская О. М., Регель К. В. Паразиты (гельминты, пиявки и ракообразные) животных // Растительный и животный мир заповедника «Магаданский». Магадан : СВНЦ ДВО РАН, 2011. С. 88-92. Приложение 4. Паразиты. С. 227-246. 
Атрашкевич Г. И., Орловская О. М., Регель К. В., Михайлова Е. И., Поспехов В. В. Паразитические черви животных Тауйской губы // Биологическое разнообразие Тауйской губы Охотского моря. Владивосток : Дальнаука, 2005. C. 175-251.

Балданова Д. Р., Пронин Н. М. Скребни (тип Acanthocephala) Байкала: Морфология и экология. Новосибирск : Наука, 2001. 158 с. (Справочники и определители по фауне и флоре озера Байкал).

Белогуров О. И. Паразитические черви наземных позвоночных материкового побережья Охотского моря (фауна, экология, география) : автореф. дис. ... канд. биол. наук. Владивосток, 1965. 20 с.

Буторина Т. Е., Бусарова О. Ю., Ермоленко А. В. Паразиты гольцов (Salmonidae: Salvelinus) Голарктики. Владивосток : Дальнаука, 2011. 281 с.

Быховская-Павловская И. Е. Паразиты рыб : руководство по изучению. Ленинград : Наука, 1985. 121 с.

Волобуев В. В., Поспехов В. В., Хаменкова Е. В. Размножение, экология молоди и гельминтофауна жилой кунджи Salvelinus leucomaenis озерно-речной системы Чукча (континентальное побережье Охотского моря) // Сб. науч. трудов Магаданского НИИ рыб. хоз-ва и океанографии. Магадан : МагаданНИРО, 2001. Вып. 1. С. 218-231.

Делямуре С. Л., Скрябин А. С., Сердюков А. М. Основы цестодологии. Т. 11. Дифиллоботрииды - ленточные гельминты человека, млекопитающих и птиц. Москва : Наука, 1985. 200 с.

Леонов С. А. К изучению гельминтофауны рыб озера Джека Лондона (бассейн Верхней Колымы) // Биологические проблемы Севера : тез. докл. XI Всесоюз. симпоз. Якутск, 1986. Вып. 4. С. 139-140.

Леонов С. А., Обушенков И. Н. Гельминтофауна рыб, водоплавающих и рыбоядных птиц и млекопитающих района создания водохранилища Колымской ГЭС // Пояс редколесий верховий Колымы (район строительства Колымской ГЭС). Владивосток : ДВНЦ АН СССР, 1985. С. 139-151 (Биологические проблемы Севера).

Михайлова Е. И. Скребни рода Neoechinorhynchus (Acanthocephales: Neoechinorhynchidae) северо-восточной Азии (таксономия, зоогеография, экология) : автореф. дис. ... канд. биол. наук. Санкт-Петербург, 2015. 22 c.

Михайлова E. И. О распространении скребня Neoechinorhynchus tumidus (Eoacanthocephala: Neoechinorhynchidae) в Северной Азии // Паразитология. 2020. Т. 54, № 4. С. 298-311. DOI:10.31857/ $\mathrm{S} 1234567806040033$

Михайлова Е. И., Атрашкевич Г. И., Казаков Б. Е. Проблемы изучения скребней рода Neoechinorhynchus (Acanthocephala: Neoechinorhynchidae) в России и первообнаружение N. salmonis Ching, 1984 в Палеарктике // Успехи общей паразитологии. Москва : Наука, 2004. Т. 44. С. 211-220.

Никишин В. П., Леонов С. А. Гельминты промысловых рыб бассейна Буюнды : препринт. Магадан : СВНЦ ДВО РАН, 2000. 78 с.

Однокуриев В. А. Паразитофауна позвоночных животных Якутии / отв. ред. А. И. Ануфриев. Новосибирск : Изд-во СО РАН, 2015. 309 с.

Определитель паразитов пресноводных рыб фауны СССР. Т. 3. Паразитические многоклеточные. Ч. 2.
Ленинград : Наука, 1987. 583 с. (Определители по фауне СССР, изд. Зоол. ин-том АН СССР ; вып. 149).

Орловская О. M. Метацеркарии стригеидид (Trematoda: Strigeidida) в пресноводных гидроценозах Охотско-Колымского края // Паразиты рыб: современные аспекты изучения. Борок : ИБВВ РАН, 2003. C. $40-41$.

Орловская О. М., Атрашкевич Г. И. К познанию жизненных циклов трематод Чукотки // Гельминтология сегодня: проблемы и перспективы. Москва : Наука, 1989. Т. 2. С. 40-41.

Петроченко В. И. Акантоцефалы (скребни) домашних и диких животных. Москва : Изд-во АН СССР, 1956. T. $1.435 \mathrm{c}$.

Поспехов B. В. Гельминты и паразитические ракообразные рыб озерно-речной системы Чукча (бассейн p. Тауй, Охотское море) // Известия ТИНРО. 2013. T. 172. C. 165-172.

Поспехов В. В., Атрашкевич Г. И., Орловская О. М. Паразиты рыб бассейна реки Гижига (северное побережье Охотского моря) // Известия ТИНРО. 2010. T. 163. C. 365-378.

Поспехов В. В., Атрашкевич Г. И., Орловская О. М. Паразитические черви проходных лососевых рыб Северного Охотоморья. Магадан : Кордис, 2014. 128 с.

Поспехов В. В., Атрашкевич Г. И., Орловская О. М. Паразиты хариусов (Thymallidae: Thymallus) северной части материкового побережья Охотского моря // Известия ТИНРО. 2020. Т. 200, № 4. С. 965977. DOI:10.26428/1606-9919-2020-200-965-977

Протасова Е. Н., Ройтман В. А. Циатоцефаляты ленточные гельминты морских и пресноводных рыб (Cestoda: Pseudophyllidea: Cyathocephala). Москва : Б. и., 1995. 132 с. (Основы цестодологии / Рос. АН, Ин-т паразитологии; т. 12).

Пугачев О. Н. Паразиты пресноводных рыб северовостока Азии. Ленинград : Изд-во Зоол. ин-та АН CCCP, 1984. $156 \mathrm{c}$.

Пугачев О. Н. Каталог паразитов пресноводных рыб Северной Азии. Книдарии, моногенеи, цестоды // Тр. ЗИН РАН. 2002. Т. 297. 248 с.

Пугачев О. Н. Каталог паразитов пресноводных рыб Северной Азии. Трематоды: Тр. ЗИН РАН. 2003. T. 298.224 c.

Пугачев О. Н. Каталог паразитов пресноводных рыб Северной Азии. Нематоды, скребни, пиявки, моллюски, ракообразные, клещи // Тр. ЗИН РАН. 2004. T. 304. $250 \mathrm{c}$.

Скрябина E. C. Морфологическая изменчивость скребней рода Neoechinorhynchus (Acanthocephala: Neoechinorhynchidae), паразитирующих у рыб Ледовитоморской провинции в пределах СССР // Паразитология. 1978. Т. 12, № 6. С. 512-522.

Соколов С. Г. Обзор паразитов микижи Parasalmo mykiss (Osteichthyes, Salmonidae) полуострова Камчатка // Invertebrate Zoology. 2005. T. 2 Вып. 1. С. 3560.

Соколов С. Г., Гордеев И. И. Зараженность озерного бокоплава Gammarus lacustris Sars, 1863 (Amphipoda: Gammaridae) гельминтами в оз. Кроноцкое (Камчатка) // Паразитология, 2014. Т. 48. Вып. 4. С. 325332.

Судариков B. E. Трематоды фауны СССР. Стригеиды. Москва : Наука, 1984. 168 с. 
Черешнев И. А., Шестаков А. В., Скопеи М. Б. Определитель пресноводных рыб Северо-Востока России. Владивосток : Дальнаука, 2001. 129 с.

Шигин A. A. Трематоды фауны CСCР. Род Diplostoтит. Метацеркарии. Москва : Наука, 1986. 254 с.

Amin O. M. Revision of Neoechinorhynchus Stiles \& Hassal, 1905 (Acanthocephala: Neoechinorhynchidae) with keys to 88 species // Systematic Parasitology. 2002. Vol. 53, No. 1. P. 1-18.

Amin O. M., Heckmann R. A., Baldanova D. R. Revisiting Echinorhynchid Acanthocephalans in Lake Baikal with the Use of Scanning Electron Microscopy, with some Taxonomic reconsiderations // Comparative Parasitology. 2015. Vol. 82, No. 1. P. 29-39. DOI: 10.1654/4750.1.

Arai H. P. Acanthocephalan // Guide to the parasites of fishes of Canada / Eds L. Margolis, Z. Kabata. Part 3. Canadian Special Publication of Fisheries and Aquatic Sciences. 1989. Vol. 107. 95 p.

Bauer O. N. Parasites and diseases of USSR coregonids // Biology of coregonid fishes / Eds. C. C. Lindsey, C. S. Woods. Winnipeg : Univ. of Manitoba Press, 1970. P. 267-278.

Caira J. N., Jensen K., Waeschenbach A., Olson P. D., Littlewood D. T. J. Orders out of chaos - molecular phylogenetics reveals the complexity of shark and stingray tapeworm relationships // International Journal for Parasitology. 2014 . Vol. 44, No. 1. P. 55-73. DOI: 10.1016/j. ijpara.2013.10.004
Hoffman G. L. Parasites of North American freshwater fishes. New York : Comstock Publishing Associates, 1999. 539 p.

Kuchta R., Scholz T., Brabec J., Bray R. Suppression of the tapeworm order Pseudophyllidea (Platyhelminthes: Eucestoda) and the proposal of two new orders, Bothriocephalidea and Diphyllobothriidea // International Journal for Parasitology. 2008. Vol. 38, No. 1. P. 49-55. DOI:10.1016/j.ijpara.2007.08.005

Margolis L., Arthur J. R. Synopsis of the parasites of fishes of Canada // Bulletin of the Fisheries Research Board of Canada. Ottawa, 1979. No. 199. 269 p.

Reier S., Sattmann H., Schwaha T., Fuehrer H.-P., Haring E. Unravelling the hidden biodiversity - the establishment of DNA barcodes of fish-parasitizing Acanthocephala Koehlreuther, 1771 in view of taxonomic misidentifications, intraspecific variability and possible cryptic species // Parasitology. 2020. Vol. 147. P. 1499-1508. DOI:10.1017/S0031182020001316

Waeschenbach A., Brabec J., Scholz T., Littlewood D. T. J., Kuchta R. The catholic taste of broad tapeworms multiple routes to human infection // International Journal for Parasitology. 2017. Vol. 47, No. 13. P. 831-843. DOI:10.1016/j.ijpara.2017.06.004

Wayland M. T., Vainio J. K., Gibson D. I., Herniou E. A., Littlewood D. T., Väinölä, R. The systematics of Echinorhynchus Zoega in Müller, 1776 (Acanthocephala, Echinorhynchidae) elucidated by nuclear and mitochondrial sequence data from eight European taxa // ZooKeys. 2015. Vol. 484. P. 25-52. DOI:10.3897/zookeys.484.9132

\title{
PARASITES OF THE FISH FROM MOUNTAIN LAKES IN THE UPPER KOLYMA BASIN. 1. BOLSHOY AND MALY DARPIR LAKES
}

\author{
V. V. Pospekhov, G. I. Atrashkevich, O. M. Orlovskaya, E. I. Mikhailova
}

\author{
Institute of Biological Problems of the North, FEB RAS, Magadan
}

The first data on the parasite fauna of fish from the mountain lakes Bolshoy and Maly Darpir at the southern spurs of the Chersky Ridge (Momsky District, Yakutia) are presented. 7 species of fish have been studied, in which 34 species of parasites have been found: 33 species of helminths and 1 species of parasitic copepods, belonging to 22 genera, 16 families, 12 orders, 7 classes of 4 types of the animal kingdom. Trematodes completely dominate by the number of species among helminths (16 species); cestodes are half as many ( 8 species); these are followed by nematodes and spiny-headed worms (5 and 4 species, respectively). The greatest variety of parasites was found in the East Siberian grayling (22 species) and the Arctic char (19 species). Next to the latter in terms of the number of parasite species, there went the Kolyma sculpin (13 species), round whitefish (10 species each), sucker (9 species), eelpout, and common minnow (7 species each). Only one parasite species, the Neoechinorhynchus salmonis Ching, 1984 spiny-headed worm, is common for all studied fish. The second species of spiny-headed worms, Pseudoechinorhynchus borealis (Linstow, 1901), not found only in the round whitefish, was first recorded in fish of the Okhotsk-Kolyma area and in the sucker as a new definitive host.

Keywords: ichthyoparasite fauna, cestode, trematode, nematode, spiny-headed worms, mountain lakes, the Upper Kolyma basin. 


\section{REFERENCES}

Amin, O. M., 2002. Revision of Neoechinorhynchus Stiles \& Hassal, 1905 (Acanthocephala: Neoechinorhynchidae) with Keys to 88 Species, Systematic Parasitology. 53 (1): 1-18.

Amin, O. M., Heckmann, R. A., Baldanova, D. R., 2015. Revisiting Echinorhynchid Acanthocephalans in Lake Baikal with the Use of Scanning Electron Microscopy, with Some Taxonomic Reconsiderations, Comparative Parasitology. 82 (1): 29-39. DOI:10.1654/4750.1

Andreev, A. V., Slobodin, S. B., Khamenkova, E. V., 2020. Ruthless Exploration of Kolyma, Last Frontier Southern Part of the Chersky Ridge. Nature. (6): 32-45 [In Russian]. DOI:10.7868/S0032874X20060046

Arai, H. P., 1989. Acanthocephalan. Eds. L. Margolis and Z. Kabata, Guide to the Parasites of Fishes of Canada. Part 3. Canadian Special Publication of Fisheries and Aquatic Sciences. 107.

Atrashkevich, G. I., Mikhailova, E. I., Orlovskaya, O. M., Pospekhov, V. V., 2016. Biolodiversity of Acanthocephalans (Acanthocephala) in Freshwater Fishes of the Asiatic Subarctic Region, Parazitologiya, 50 (4), 263290 [In Russian].

Atrashkevich, G. I., Orlovskaya, O. M., Regel, K. V., 2011. Parasites (Helminthes, Leeches, and Crustaceans) of Animals, Flora and Fauna of the Magadansky Reserve. Magadan, NESC FEB RAS. 88-92. Appendix 4. Parasites, 227-246 [In Russian].

Atrashkevich, G. I., Orlovskaya, O. M., Regel, K. V., Mikhaylova, E. I., Pospekhov, V. V., 2005. Parasitic Worms of the Tauysk Bay, Biodiversity in the Tauysk Bay of the Sea of Okhotsk. Vladivostok, Dalnauka. 175-251 [In Russian].

Baldanova, D. R., Pronin, N. M., 2001. Acanthocephalans (Phylum Acanthocephala) of Baikal: Morphology and Ecology. Novosibirsk, Nauka (Guides and Keys to Identification of Fauna and Flora of Lake Baikal) [In Russian].

Bauer, O. N., 1970. Parasites and Diseases of USSR Coregonids. Eds. C. C. Lindsey and C. S. Woods, Biology of Coregonid Fishes. Winnipeg, Univ. of Manitoba Press. 267-278.

Belogurov, O. I., 1965. Parasitic Worms of Terrestrial Vertebrates from the Sea of Okhotsk Continental Coast (Fauna, Ecology, Geography). Avtoref. Dis. ... Kandidata Biol. Nauk. Vladivostok [In Russian].

Butorina, T. Ye., Busarova, O. Yu., Yermolenko, A. V., 2011. Parasites of Char (Salmonidae: Salvelinus) from the Holarctic. Vladivostok, Dalnauka [In Russian].

Bykhovskaya-Pavlovskaya, I. E., 1985. Fish Parasites: Study Manual. Leningrad, Nauka [In Russian].

Caira, J. N., Jensen, K., Waeschenbach, A., Olson, P. D., Littlewood D. T. J., 2014. Orders out of Chaos - Molecular Phylogenetics Reveals the Complexity of Shark and Stingray Tapeworm Relationships, International Journal for Parasitology. 44 (1), 55-73. DOI: 10.1016/j. ijpara.2013.10.004

Chereshnev, I. A., Shestakov, A. V., Skopets, M. B., 2001. Guide to Freshwater Fishes in the Russian NorthEast. Vladivostok, Dalnauka [In Russian].

Delyamure, S. L., Skrjabin, A. S., Serdyukov, A. M., 1985. Basics of Cestodology. Diphyllobothrium Species - Tapeworms of Humans, Mammals, and Birds. Vol. XI. Moscow, Nauka [In Russian].
Hoffman, G. L., 1999. Parasites of North American Freshwater Fishes. Comstock Publishing Associates.

Key to Parasites of Freshwater Fish of the USSR Fauna: Parasitic Multicellulars, 1987. Ed. Bauer O. N. Leningrad, Nauka. 3, Part 2 [In Russian].

Kuchta, R., Scholz, T., Brabec, J., Bray, R., 2008. Suppression of the Tapeworm Order Pseudophyllidea (Platyhelminthes: Eucestoda) and the Proposal of Two New Orders, Bothriocephalidea and Diphyllobothriidea, International Journal for Parasitology. 38 (1), 49-55. DOI:10.1016/j.ijpara.2007.08.005

Leonov, S. A., 1986. On Studying the Helminth Fauna in the Fishes of Lake Jack London (Upper Kolyma Basin). Biological Problems of the North. $11^{\text {th }}$ All-Union Symposium, Abstracts. Yakutsk. 4, 139-140 [In Russian].

Leonov, S. A., Obushenkov, I. N., 1985. Helminth Fauna of Fish, Waterfowl, and Fish-Eating Birds and Mammals in the Construction Area of Kolyma HPP Reservoir, The Belt of Rare Forests of the Upper Kolyma River (Kolyma HPP Construction Area). Vladivostok, FESC AS USSR. 139-151 (Biological Problems of the North) [In Russian].

Margolis, L., Arthur, J. R., 1979. Synopsis of the Parasites of Fishes of Canada, Bulletin of the Fisheries Research Board of Canada. Ottawa. 199.

Mikhaylova, E. I., 2015. Spiny-Headed Worms of the Genus Neoechinorhynchus (Acanthocephales: Neoechinorhynchidae) from Northeast Asia (Taxonomy, Zoogeography, and Ecology). Autoref. Dis. ... Kandudata Biol. Nauk, St. Petersburg [In Russian].

Mikhailova, E. I., 2020. On the Distribution of the Neoechinorhynchus tumidus (Eoacanthocephala: Neoechinorhynchidae) in North Asia, Parasitologiya. 50 (4), 298-311. DOI:10.31857/S1234567806040033 [In Russian].

Mikhailova, E.,I., Atrashkevich, G.,I., Kazakov, B.,E., 2004. Problems of Studying Acanthocephalans Neoechinorhynchus (Acanthocephala: Neoechinorhynchidae) in Russia and the First Finding of N. salmonis Ching, 1984 in Palaearctic, Achevements in General Parasitology. Moscow, Nauka. 44. 211-220 [In Russian].

Nikishin, V. P., Leonov, S. A., 2000. Helminths of the Buyunda Basin Commercial Fishes. Preprint. Magadan, NESC FEB RAS [In Russian].

Odnokurtsev, V. A., 2015. Parasite Fauna of Vertebrate Animals in Yakutia. Novosibirsk, SB RAS [In Russian].

Orlovskaya, O. M., 2003. Metacerkaria of Strigeatids (Trematoda: Strigeidida) in the Freshwater Hydrocenoses of the Okhotsk-Kolyma Region, Fish Parasites: Modern Aspects of Study. Borok, IBIW RAS. 40-41 [In Russian].

Orlovskaya, O. M., Atrashkevich, G. I., 1989. On the Knowledge of Life Cycles of Chukotka's Trematodes Helminthology Today: Problems and Prospects. Moscow, Nauka. 2, 40-41 [In Russian].

Petrochenko, V. I., 1956. Acanthocephalans (Proboscis Worms) of Domestic and Wild Animals. Moscow, AS USSR. 1 [In Russian].

Pospekhov, V.,V., 2013. Helminthes and Parasitic Crustaceans of Fish in the Chukcha Lake-River System (Tauy River Basin, Sea of Okhotsk), Izvestiya TINRO. 172, 165-172 [In Russian]. 
Pospekhov, V.V., Atrashkevich, G. I., Orlovskaya, O. M., 2010. Fish Parasites from the Gizhiga River Basin (Northern Coast of the Sea of Okhotsk), Izvestiya TINRO. 163, 365-378 [In Russian].

Pospekhov, V.V., Atrashkevich, G. I., Orlovskaya, O. M., 2014. Parasitic Worms of Migratory Salmon Fishes in the North Sea of Okhotsk. Magadan, Kordis [In Russian].

Pospekhov, V.V., Atrashkevich, G.I., Orlovskaya, O.M., 2020. Parasites of Graylings (Thymallidae: Thymallus) from the Northern Continental Coast of the Sea of Okhotsk, Izvestiya TINRO. 200 (4), 965-977. DOI:10.26428/16069919-2020-200-965-977 [In Russian].

Protasova, E. N., Roytman, V. A., 1995. Foundations of Cestodology. Vol. XII. Cyathocephalates, Tapeworm Helminth of Marine and Freshwater Fish Cestoda: Pseudophyllidea: Cyathocephala). Moscow, Institute of Parasitology RAS [In Russian].

Pugachev, O. N., 1984. Parasites of Freshwater Fishes in Northeast Asia. Leningrad, ZIN AS SSSR [In Russian].

Pugachev, O. N., 2002. Catalog of Freshwater Fish Parasites in North Asia: Knidarians, Monogeneans, and Cestodes, Proceedings of the Zoological Institute RAS. 297 [In Russian].

Pugachev, O. N., 2003. Catalog of Freshwater Fish Parasites in North Asia: Trematodes, Proceesings of the Zoological Institute RAS. 298 [In Russian].

Pugachev, O. N., 2004. Catalog of Freshwater Fish Parasites in North Asia: Nematoda, Acanthocephala, Hirudinea, Mollusca, Crustacea, Acari, Proceedings of the Zoological Institute RAS. 304 [In Russian].

Reier, S., Sattmann, H, Schwaha, T., Fuehrer, H.-P., Haring, E., 2020. Unravelling the Hidden Biodiversity - the Establishment of DNA Barcodes of Fishparasitizing Acanthocephala Koehlreuther, 1771 in View of Taxonomic Misidentifications, Intraspecific Variability and
Possible Cryptic Species, Parasitology. 147, 1499-1508. DOI:10.1017/S0031182020001316

Shigin, A. A., 1986. Trematodes of the USSR Fauna. Genus Diplostomum. Metacercaria. Moscow, Nauka [In Russian].

Skrjabina, E. S., 1978. Morphological Variability of Thorny-headed Worms of the Genus Neoechinorhynchus (Acanthocephala: Neoechinorhynchidae) from Fishes of Waterbodies in the Arctic of the USSR, Parazitologiya, 12 (6), 512-522 [In Russian].

Sokolov, S. G., 2005. A Review of Parasites of the Mikizha Parasalmo Mykiss (Osteichthyes, Salmonidae) from the Kamchatka Peninsula, Invertebrate Zoology. 2 (1), 35-60 [In Russian].

Sokolov, S. G., Gordeev, I. I., 2014. Occurrence of Helminths in Amphipods Gammarus lacustris Sars, 1863 (Amphipoda: Gammaridae) from Lake Kronotskoye (Kamchatka), Parasitologiya. 48 (4), 325-332 [In Russian].

Sudarikov, V. E., 1984. Trematodes of the USSR Fauna. Strigeids. Moscow, Nauka [In Russian].

Volobuyev, V. V., Pospekhov, V. V., Khamenkova, E. V., 2001. Reproduction, Juvenile Ecology, and Helminthofauna of Non-Anadromous Kundscha Salvelinus leucomaenis from the Chukcha Lake-River System (Continental Coast of the Sea of Okhotsk), Proceedings of MagadanNIRO. Magadan. 1, 218-231 [In Russian].

Waeschenbach, A., Brabec, J., Scholz, T., Littlewood, D. T. J., Kuchta, R., 2017. The Catholic Taste of Broad Tapeworms - Multiple Routes to Human Infection, International Journal for Parasitology. 47 (13), 831-843. DOI:10.1016/j.ijpara.2017.06.004

Wayland, M. T., Vainio, J. K., Gibson, D. I., Herniou, E. A., Littlewood, D. T., Väinölä, R., 2015. The Systematics of Echinorhynchus Zoega in Müller, 1776 (Acanthocephala, Echinorhynchidae) Elucidated by Nuclear and Mitochondrial Sequence Data from Eight European Taxa. ZooKeys. 484, 25-52. DOI:10.3897/zookeys.484.9132 